\title{
Still Influential: The Protestant Emphasis on Schooling
}

\author{
Horst Feldmann \\ Department of Economics, University of Bath, UK \\ h.feldmann@bath.ac.uk
}

\begin{abstract}
From its beginning 500 years ago, Protestantism has been advocating and actively pursuing the expansion of schooling, including the schooling of girls. In many countries, it has thus helped to create a cultural heritage that puts a high value on education and schooling. This paper provides evidence that Protestantism's historical legacy has an enduring effect. Using data on 147 countries, it finds that countries with larger Protestant population shares in 1900 had higher secondary school enrollment rates over 1975-2010, including among girls. The magnitude of the effect is small though. Using Protestant population shares over 1975-2010, the paper also shows that Protestantism's influence on schooling has diminished and that contemporary Protestantism, in contrast to historical Protestantism, does not affect schooling. The regression analysis accounts for numerous other determinants of schooling.
\end{abstract}

\section{Keywords}

education - Protestantism - religion - schooling

\section{Introduction}

Religion has shaped education since ancient times. A comparatively recent example is Protestantism. Right from the start of the Reformation, this religion has stressed the importance of education and schooling and has made strenuous efforts to expand them. Is this emphasis still influential today? On the one hand, Protestantism remains one of the major world religions. About $12 \%$ of the global population adhere to it, with the population shares being much

(C) HORST FELDMANN, 2018 | DOI:10.1163/15691330-12341474

This is an open access article distributed under the terms of the prevailing CC-BY-NC license at the time of publication. 
higher in Nordic, several other European, Anglo-Saxon and numerous developing countries (Pew Research Center 2011). On the other hand, since the 19th century the formal role of religion in education has been strongly diminished, especially in the West. Education was almost completely secularized and the school systems were taken over by the state, either entirely or for the most part (Boyd and King 1975). What is more, since the mid-2oth century governments in most countries around the world have dramatically expanded secondary schooling - regardless of their countries' dominant religions (Lee and Lee 2016, Pew Research Center 2016).

Using data on 147 countries, this paper econometrically studies the influence of Protestantism, particularly its historical legacy, on contemporary schooling specifically, on secondary schooling over the period $1975^{-2010}$. So far, there are just two papers econometrically analyzing the effect of Protestantism (and other world religions) on education around the globe (Norton and Tomal 2009, Feldmann 2016a). However, both focus on religion's contemporary influence, not on its historical legacy. Neither of them finds a statistically significant effect of Protestantism. Most previous papers study the United States. They, too, focus on contemporary effects. According to these papers, in this country the type of Protestantism matters, with educational attainment being the lowest among fundamentalists and Pentecostals, and mainline Protestants being at the center of the distribution (e.g., Lehrer 1999, Beyerlein 2004, Massengill 2008). Other econometric studies take a purely historical perspective, finding that Protestantism had a positive impact on schooling and educational outcomes in 19th century Prussia and Switzerland (e.g., Becker and Woessmann 2009, Boppart et al. 2013).

The paper that comes closest to our approach is by Gallego and Woodberry (2010). Using cross-region data for a sample of 17 African countries, they econometrically study the effects of Protestant versus Catholic missionary activity around 1900 on educational outcomes in the 1990s - specifically, on literacy rates and average years of schooling of the adult population. They find that Protestant missionary activity around 1900 had a substantial positive effect on educational outcomes in the 1990s, especially in areas where the Protestant missionaries had competed with Catholic missionaries. By contrast, the effect of Catholic missionaries was small or insignificant, especially in areas where they had been protected from Protestant competition in the past.

Our paper proceeds as follows. Section 2 summarizes the evolution of Protestantism's influence on schooling. Section 3 describes our variables. Section 4 explains both our sample and methodology. Section 5 presents and discusses our regression results. Section 6 concludes. 
The Reformation began in 1517 when Martin Luther (1483-1546), an Augustinian monk and a professor of theology at the University of Wittenberg, publicly criticized the established Roman Catholic Church for its claims and abuses of the day (e.g., the sale of indulgencies). ${ }^{1}$ The Reformation quickly spread throughout western and northern Europe. Although it soon led to the formation of different churches such as Calvinism in Switzerland and Anglicanism in England, Luther remained its intellectual leader (Mitchell 1993). He developed a concept of education, which he and his fellow German reformers helped to implement throughout the Protestant states of Germany. Their educational plans became a model for many other countries of western and northern Europe that had broken away from Rome (Boyd and King 1975). Indeed, from the 16th to the 18th century Protestant Germany was the European leader in educational theory and practice (Hans 1967).

Luther demanded compulsory elementary education for boys and girls of all social classes (Bowen 1975, Boyd and King 1975). His prime concern was with the promotion of Christian faith. In his view, the masses needed education mainly because everyone should be able to read the Bible, the primary authority in all matters of faith and morals (Bowen 1975, Hans 1967). Therefore, as the first step in his educational endeavor, he translated it into German. Religious instruction, and the Bible in particular, were to form an important part of the school curriculum. All instruction was to be in the vernacular (Bowen 1975). Luther gave explicit approval to secular knowledge too. In his view, each individual had a particular vocation in the world. Children needed to be prepared to become orderly and productive citizens. Therefore, schools should also teach secular and practical subjects such as mathematics (Harran 1997). Additionally, Luther promoted vocational education (Hans 1967). Religious and secular education should be combined to enable people to fulfill their appropriate stations in life (Mitchell 1993). The co-reformer and Humanist Philip Melanchthon (1497-1560) developed a system of three-stage progression at school (Bowen 1975): good pupils should progress from the elementary stage to a second stage, and the very best students (irrespective of their social background) should subsequently be prepared for university. According to Luther, all teaching should be performed by well-trained teachers, including women (Bowen 1975). Luther and Melanchthon placed the responsibility for the establishment, maintenance and inspection of schools on the state, which should

1 For the history, worldview and principles of Protestantism, see, e.g., McGrath (2007) and Ryrie (2017). 
also secure the attendance of the children (Strauss 1978). Every town should have both a boys' and a girls' school (Becker and Woessmann 2009).

In Germany at the time of the Reformation, the number of schools was small and less than $1 \%$ of the population was literate (Engelsing 1973, Green 1979). However, from the late 1520 numerous schools were founded on the model developed by Luther and Melanchthon (Strauss 1978). Saxony adopted it immediately. Other cities, regions and countries soon followed - for example, Hamburg in 1529 and Palatine in 1556 (Bowen 1975, 1981). Universities, too, were reformed and founded along Reformist lines (Paulsen 1908, Holborn 1959). In the 1540s, Saxony established the first institutional system of schools, as distinct from individual town schools (Bowen 1981). In Brandenburg between 1539 and 1573-1600, the number of boys' schools increased from 55 to 100 and the number of girls' schools from 4 to 45 (Green 1979). In the 16th century, universal education for boys and girls was also introduced in the southern state of Württemberg, paving the way for both high social mobility and a remarkably large contribution of this state to German intellectual history over the following centuries (Green 1979).

From the late 17th century, the newly emerged state of Prussia reformed and founded universities, and the Protestant educational reformer August Francke (1663-1727) further developed the German system of secondary education (Schleunes 1989). His schools were open to boys and girls, and free of charge for children from poor families. Under Francke's influence, Prussia took the educational lead in Europe in the 18th century (Bowen 1981).

In Scandinavia, the Lutheran Reformation was accepted soon after its start. It quickly became one of the most important factors of national life. As in Germany, it led to universal elementary education. Early school laws were enacted as part of church law for Denmark in 1537, Norway in 1539 and Sweden in 1571 (Hans 1967). They called for compulsory elementary education of all children. According to a Danish and Norwegian law of 1739, every parish had to erect a school house. Teachers were appointed by the local pastor. In Sweden, all school edicts were made by the clergy, who insisted on literacy as a condition for marriage and participation in Holy Communion (Hans 1967).

In Britain, where Protestantism prevailed over Roman Catholicism in the second half of the 16th century after some back and forth, the new religion also exercised a direct and lasting influence on education (Bowen 1981). Additionally, Britain exported Protestantism to its colonies around the globe, thus profoundly shaping their educational systems too. For example, in the thirteen British colonies that later formed the United States various Protestant churches and sects established schools - e.g., the Anglican Church, Quakers, German Lutherans and Pietists, Presbyterians and Puritans (Cremin 1970). For the most part, schools in the thirteen colonies were instruments of the 
Protestant Reformation (Welter 1962). In Massachusetts, Puritans pushed through legislation in 1642 and 1647 that set up elementary and grammar schools for the express purpose of fostering literacy and the Puritan version of the Protestant faith (Elias 2002). With its laws of 1642 and 1647, Massachusetts led the way in compulsory education in North America (Hans 1967).

The achievements of the Protestants in North America were remarkable. By the middle of the 18th century, literacy in New England approached $85 \%$ among men and 50\% among women (Reich 2011). These were exceptionally high figures, even by the standards of western Europe (Engerman et al. 2009). Indeed, by the time of the American Revolution (1765-1783) education in the thirteen British colonies "was more accessible [...] than in any nation of Western Europe" (Reich 2011, p. 215). Furthermore, the curriculum was broadened and modernized early on: in the thirteen colonies, secondary schools began introducing modern languages, mathematics, science, history and commercial subjects already before independence.

Even after the US had declared independence, Britain had a vast colonial empire, spanning all continents. Here, too, Protestants introduced mass education. In its colonies, the British government largely left education in the hands of missions (Clignet and Foster 1964). It subsidized missionary schools, provided they met minimum standards (Gifford and Weiskel 1971). This approach stimulated competition among missions of various denominations, resulting in a rapid proliferation of missionary schools (Frankema 2012). In British colonies, missionaries were predominantly Protestant. Unlike their Catholic rivals, Protestant missionaries did not only intend to win converts to Christianity. They also wanted to enable the new Christians to read the Bible (Berman 1975). Therefore, Protestant missionaries placed high emphasis on spreading the key skill of reading. While in both Spanish and French colonies the language of the colonial power was the sole language of instruction, excluding a large majority of native children from schooling, in British colonies teaching was in the local vernacular in the first grades, enabling practically all native children to enter school (Feldmann 2016b). Furthermore, the Protestant missionaries introduced formal education for women as well as for marginalized groups such as slaves or members of the "untouchable" castes in India (White 1996, Bellenoit 2007). As a result of these various features, through the colonial period primary school enrollment rates were substantially higher in British than in, for example, French colonies. By 1935-40 they reached $40 \%$ in the former, compared with $24 \%$ in the latter (Benavot and Riddle 1988).

The Protestant missionaries in the British colonies were also the first to provide post-primary education (Berman 1975). Indeed, British colonies had more secondary schools and universities than, for example, French colonies, although before 1945 the absolute number of these institutions remained small 
in the British colonies too (Clignet and Foster 1964, Gifford and Weiskel 1971). As other colonial rulers, until the period of decolonization the British tried to confine advanced education of locals to a small employable number, in order to avoid the creation of nationalist movements (Gifford and Weiskel 1971, Bellenoit 2007).

From the 19th century, Protestantism's influence on schooling was on the wane in traditionally Protestant countries. Partly due to Enlightenment, their school systems drifted into a more and more secular direction. In Germany, this development culminated in the Weimar Constitution of 1919, which provided for a separation of church and state and declared that the entire school system, including religious and private schools, was under supervision of the state (Lamberti 2002). Under the totalitarian regimes of the 2oth century Nazi Germany (1933-1945) and Communist East Germany (1949-1990) - the Protestant Church lost whatever little influence had remained. Since German reunification in 1990, the West German Basic Law of 1949 applies to the whole of Germany. It repeats the provision of the Weimar Constitution that the entire school system shall be under the supervision of the state (Beuttler 2012). Although the Protestant church of Germany still claims its co-responsibility for public education (Kirchenamt der Evangelischen Kirche in Deutschland 2013), its influence is hardly discernible - mainly because Germany has long become a largely secular society (Beuttler 2012).

Similar developments occurred in other traditionally Protestant countries over the 19th and 2oth centuries. For example, in Switzerland the constitution of 1874 stipulated the total secularization of education (Criblez 1999). In Denmark and Norway too, the whole school system was taken over by the state in the 19th century (Hans 1967). The Swedish school system was entirely secularized in the first third of the 2oth century. In England, where the Anglican Church is a state church, the confessional element in state schools was reduced to an absolute minimum after World War II (Mitchell 1993). In the United States, the emergence of state-sponsored education in the early 19th century undermined the hitherto strong Protestant influence on schooling (Nord 1995). From the 196os, the Supreme Court strengthened the division between institutional religion and state-sponsored education (Vergon 1986). Since then, public schools in the US offer a strictly secular education and any influence of Protestant churches on formal education is limited to private schools (Mitchell 1993).

In developing countries, Protestantism's influence on schooling had a more mixed record in recent times. On the one hand, afterindependence many ex-colonies created state schools by nationalizing mission schools (Woodberry 2012). This reduced Protestantism's influence, not least because in most ex-colonies 
the education provided in state schools is largely secular (Benavot and Resnik 2006). On the other hand, Protestantism has spread rapidly in most developing countries over recent decades, attenuating the decline of Protestantism's influence through secularization. One case in point is Africa, where the Protestant population share increased from about $2 \%$ in 1900 to more than $27 \%$ in 2000 (Woodberry and Shah 2004). In many African countries, Protestant churches continue to impart the value of formal education on their adherents and lobby policy makers to expand educational provision (Sundkler and Steed 2000). In several African countries such as Cameroon, Zambia and Namibia, schooling is even still partly funded and performed by Protestant churches (Jeynes 2012).

However, most of the growth of Protestantism in developing countries over recent decades is due to the rise of Pentecostalism. One case in point is Latin America, where the Protestant population share increased from $2.5 \%$ in 1900 to $17 \%$ in 2000 after restrictions against Protestants had been lifted in these historically Catholic countries (Woodberry and Shah 2004). In recent decades a substantial number of Christians in Latin America have switched from the Catholic Church to Protestantism, and mostly to its Pentecostal variety. In 2013-14, Pentecostals accounted for two-in-three Protestants in Latin America (Pew Research Center 2014). In developed countries, the share of Pentecostals among Protestants is on the rise as well. The rise of Pentecostalism is relevant for this paper because, in contrast to mainline Protestantism, Pentecostalism does not particularly emphasize the importance of education (Woodberry and Shah 2004). Pentecostals are more given to spiritual experience and feelings (Cox 1995, Romeiro 2012). The mystic character of Pentecostalism (e.g., speaking in tongues, belief in miracles) is not conducive to secular education (Pew Research Center 2006). Some Pentecostals even oppose educating their children in public schools (Sikkink 1999).

In spite of secularization, which has strongly diminished the influence of contemporary Protestantism on schooling in most countries, the historical legacy of Protestantism in schooling may still be influential today. Indeed, using data from the World Values Surveys from the 1980 os and 1990s on 65 countries, Inglehart and Baker (2000) find that the historically dominant religion - such as Protestantism - has shaped the national culture of a given society, with enduring effects on a wide range of contemporary values and beliefs among the population - even in countries where nowadays most people have little or no contact with religious institutions. Although Inglehart and Baker (2000) do not study the effects of religious traditions on schooling, they hypothesize that the impact of these traditions on contemporary values and beliefs is transmitted partly by educational institutions. 
As Protestantism probably affects contemporary schooling primarily through its historical legacy, our main variable of interest is 'Protestantism 1900', the share of the population adhering to Protestant religion in the year 1900 (for definitions, sources and descriptive statistics of all variables, see Appendix). It covers all churches and sects that can trace their roots back to the Protestant Reformation. Examples include Lutherans, Anglicans, Methodists and Pentecostals. Counting the Anglican Church as part of the Protestant movement is in line with most of the previous literature (e.g., Bowen 1981, Pew Research Center 2011, Robinson 2012).

The year 1900 is the sole year for which historical religion data are available for many countries. The data come from the World Christian Database (Center for the Study of Global Christianity 2007). Based on censuses, surveys and estimates, this database is the only source to provide historical data on religion adherence for a large number of countries. Other databases covering many countries provide data on more recent years only. Comparing 2005 data from the World Christian Database with data from four alternative sources, Hsu et al. (2008) find that the former are highly correlated with the latter. This suggests that the data from the World Christian Database are generally reliable. Indeed, they have been used in numerous studies (e.g., Barro and McCleary 2003, Gokcekus 2008).

As an alternative to the 1900 Protestant population shares, we also use such shares from the recent past. The purpose is to study whether Protestantism's influence on contemporary schooling has diminished. The contemporary religion data are from Maoz and Henderson's (2013a) World Religion Dataset, which has been constructed only fairly recently. This dataset gives quinquennial data for all countries over the period 1945 to 2010. It mainly builds on the World Christian Database and work done by the Pew Research Center but also uses several other sources such as censuses, surveys and estimates. Maoz and Henderson (2013b) have taken great care to use the most reliable sources, reconcile conflicting data, adequately deal with missing data and to produce series that are consistent both through time and across countries. Therefore, their World Religion Dataset is probably the best country-level dataset on religion adherence currently available.

Also using data from 1900 and, alternatively, from more recent years, we control for all other major religions: Roman Catholicism, Islam and Eastern religions. ${ }^{2}$

2 We combine all Eastern religions into one variable because in our sample their joint share is small. The reference category for our religion population shares is the share of the population adhering to other religions plus the share of the non-religious population. 
According to previous empirical studies, the effects of Catholicism on education is mixed (e.g., Neal 1997, Sherkat 2011). By contrast, numerous empirical studies consistently find Islam to have a negative impact, particularly among females (e.g., Norton and Tomal 2009, Cooray and Potrafke 2011). The effects of Eastern religions have been little researched so far, with mostly inconclusive results (e.g., Norton and Tomal 2009, Bessey 2013, Feldmann 2016a). This is despite the fact that most of their dominant religions - particularly, Confucianism and Buddhism, but also Hinduism - have traditionally highly valued education (To 1993, Swarup 2000, Gamage 2011). However, some of them, especially Hinduism and also Confucianism, have traditionally neglected the education of girls (Foster Carroll 1983, Kelleher 1987). Using data from the early to mid1990s, Norton and Tomal (2009) find that, even as recent as then, countries with a larger share of Hindus had a larger share of unschooled females. In one robustness check, we additionally control for religious fractionalization because Alesina et al. (2003) and Gruber (2005) suggest that it may favorably affect education.

Our main dependent variable is the secondary school enrollment rate. ${ }^{3}$ In addition to this measure, which covers girls and boys jointly, we also use the female secondary enrollment rate. This is because, in contrast to most other religions, Protestantism has always advocated that girls should receive the same amount of education as boys. Using the female secondary enrollment rate as an alternative dependent variable enables us to gauge whether and to what extent Protestantism has benefited this demographic group in particular. We also use the male secondary enrollment rate, which further helps to compare the effects of Protestantism between genders.

We use a large number of variables to control for the impact of other potential determinants of schooling. ${ }^{4}$ The control variables we employ have been selected on the basis of the relevant theoretical and empirical literature. For brevity, instead of surveying this literature in detail let us just list the variables and cite some of the papers that have found the respective variable to be potentially important. To start with, we control for public spending on education (e.g., Trostel 2002) as well as for political rights and civil liberties (e.g., Lake and Baum 2001). We use numerous demographic variables such as life expectancy (e.g., Cervellati and Sunde 2005), death rate (e.g., Stoler and Meltzer 2013) and urbanization rate (e.g., Bertinelli and Zou 2008). Other demographic controls include the share of children in the population and, in one robustness check,

3 We do not use the primary enrollment rate because in most countries primary education has been compulsory for many years.

4 None of the control variables is strongly or moderately strongly correlated with either 'Protestantism 190o', 'Protestantism' or with any of our other religion variables. 
the population growth rate (e.g., Becker and Lewis 1973). In a further robustness check, we add the share of the elderly in the population (e.g., Poterba 1997). We also control for relevant economic characteristics. Specifically, we use GDP per capita (e.g., Mincer 1996), GDP growth rate (e.g., Méndez and Sepúlveda 2012), private credit as a proxy for credit constraints (e.g., De Gregorio 1996) and openness (e.g., Ranjan 2001). Moreover, we include dummies for ex-colonies of the former big three colonial powers: Spain, Britain and France (e.g., Feldmann 2016b). We also employ two geographic variables (e.g., Gallup et al. 1999), 'tropical area' and 'navigable waters', replacing them with 'latitude' and 'landlocked' in one robustness check. In our final check, we add 'ethnic fractionalization' (e.g., Alesina et al. 1999), alongside 'religious fractionalization' ${ }^{5}$

For two reasons, we collected data on as many countries as possible. First, Protestantism has been adopted all over the world. Second, a large sample leads to more general results. We were able to gather data on no fewer than 147 countries (for a list of countries, see Appendix).

As our main variable of interest, 'Protestantism 1900', is from a single year, we mainly use cross-sectional data and estimate the following oLs model:

$$
S_{i}=\alpha+\sum_{j=1}^{4} \beta_{j} R_{j, i}^{1900}+\sum_{k=1}^{q} \gamma_{k} X_{k, i}+\varepsilon_{i}
$$

$S_{i} \quad$ is a secondary enrollment rate variable of country $i$, covering girls and boys either jointly or separately.

$R_{j, i}^{1900}$ is a vector of our four religion 1900 variables.

$X_{k, i}$ is a vector of $q$ control variables.

$\alpha \quad$ is the constant term.

$\varepsilon_{i} \quad$ represents the error term.

The data for our enrollment and control variables are averages over 1975, 1980, 1985, 1990, 1995, 2000, 2005 and 2010. Calculating averages over eight years has the advantage of eliminating noise and reducing measurement error. We use data from these years because of data availability in the World Religion Dataset, which we use in some alternative specifications (see below). For two reasons, 1975 is the initial year for our contemporary data. First, data on both

5 In some preliminary regressions, we additionally included continent dummies. We decided not to use them in the final regressions because they turned out to be statistically insignificant, both individually and jointly. 
the enrollment variables and some of the controls are available from the early 1970 s only. Second, as we study Protestantism's effect in the recent past, going back before 1975 would not have been advisable anyway.

In one alternative specification, we replace the religion data from 1900 with averages over the eight years mentioned above. As explained in the previous section, the purpose of this is to find out whether Protestantism's effect has diminished. In a second alternative specification, which also uses contemporary religion data, we refrain from averaging the data and instead use, for all variables, the original annual data for those eight years. In this specification, we employ country fixed effects, thus exploiting variation within rather than between countries. Furthermore, we lag all explanatory variables by five years. This specification enables us to study whether, in the recent past, changes in the Protestant population share were associated with changes in secondary enrollment rates five years later. Thus whereas the estimated effect of Protestantism in the first alternative specification may still be influenced by the historical legacy of Protestantism, the second alternative specification focuses entirely on the effect of contemporary Protestantism.

The fixed effects model can be written as follows:

$$
S_{i, t}=\alpha_{i}+\sum_{j=1}^{4} \beta_{j} R_{j, i, t-5}+\sum_{k=1}^{p} \gamma_{k} X_{k, i, t-5}+\lambda_{t}+\varepsilon_{i, t}
$$

As equation 2 indicates, we additionally include year dummies, $\lambda_{t}$. This is for two reasons. First, they control for the impact of shocks that are common across countries. Second, they ensure that our estimates do not reflect overtime trends in school enrollment or religion adherence at the world level over the sample period. Note that, in contrast to equation 1 , in equation $2 R_{j, i}, t-5$ represents a vector of contemporary rather than historical religion variables. Also note that equation 2 includes no time-invariant control variables because it uses country fixed effects. Apart from this, it includes the same control variables as the baseline regressions.

Some of our religion variables as well as some of our controls may be endogenous. For example, causality may not only run from religion to education but also vice versa. Several studies using individual-level data find education to affect religiosity. ${ }^{6}$ There are no studies using country-level data that find education to affect religion adherence though. In any case, for two reasons we

6 It is unclear whether the effect of education on religiosity, if any, is positive or negative. Studies reporting a positive effect include Brañas-Garza and Neuman (2004) and Brown and Taylor (2007). Studies reporting a negative effect include Hungerman (2014), Mocan and Pogorelova (2014) and Becker et al. (2017). 


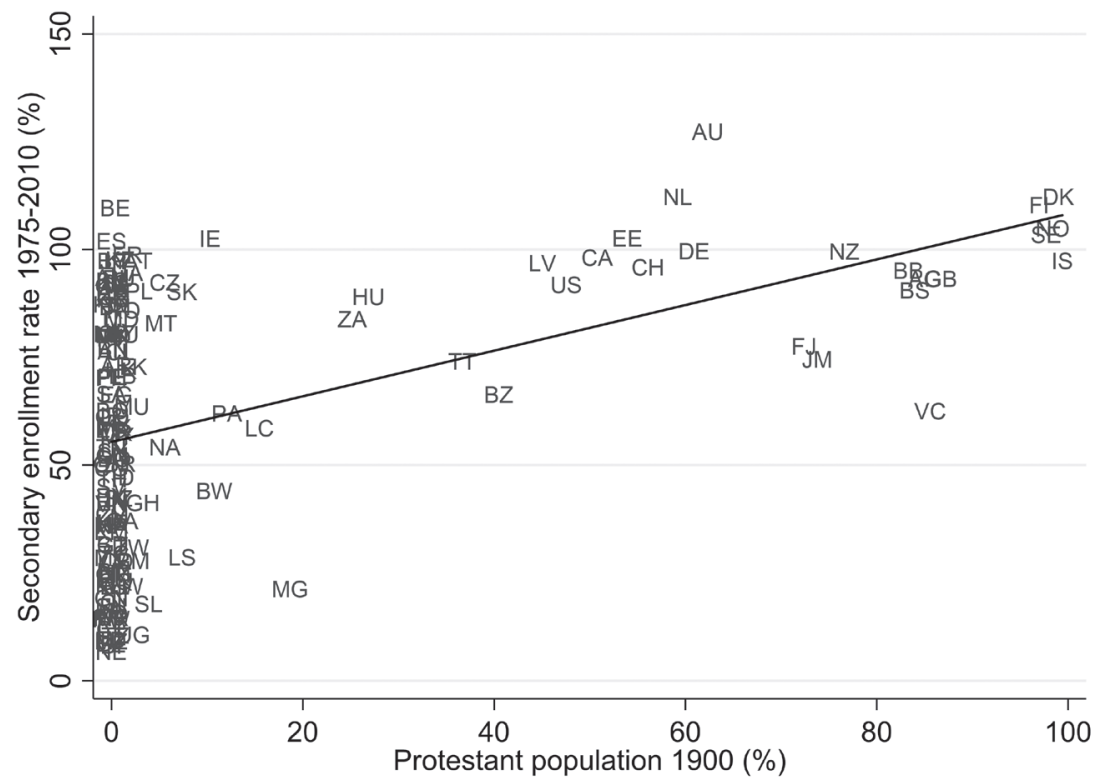

Note: 147 countries. The data for the Protestant population share are from the year 19oo. For the secondary enrollment rate, country averages are calculated using quinquennial data from the period 1975 to 2010 . The regression represented by the fitted line yields a coefficient on 'Protestant population 1900' of 0.53 (robust standard error $=0.06$ ), $\mathrm{N}=147, R^{2}=0.21$.

FIGURE 1 Protestant population share and secondary enrollment rate

instrument for none of our explanatory variables. First, instrumenting for several variables at once leads to complicated problems of identification. Second, there are no valid instruments. For example, using the Protestant population share in 1900 as an instrumental variable for the contemporary Protestant population share would not be justified. Such an approach would assume that historical Protestantism has no direct effect on contemporary schooling and that it rather affects the latter only through contemporary Protestantism. These assumptions contradict the qualitative evidence, which suggests that historical Protestantism, having long become part of the relevant countries' culture, directly affects contemporary schooling whereas contemporary Protestantism hardly affects it, if at all (section 2).

As we refrain from using instrumental variables, our regressions do not establish causality. Instead, they are used to measure conditional correlations, i.e., to assess whether our Protestantism variables are significant after controlling for other relevant factors. Still, the estimates for those variables are likely to be causal for several reasons. First, we control for most other determinants of school enrollment that have been found in the literature. Second, we ensure 


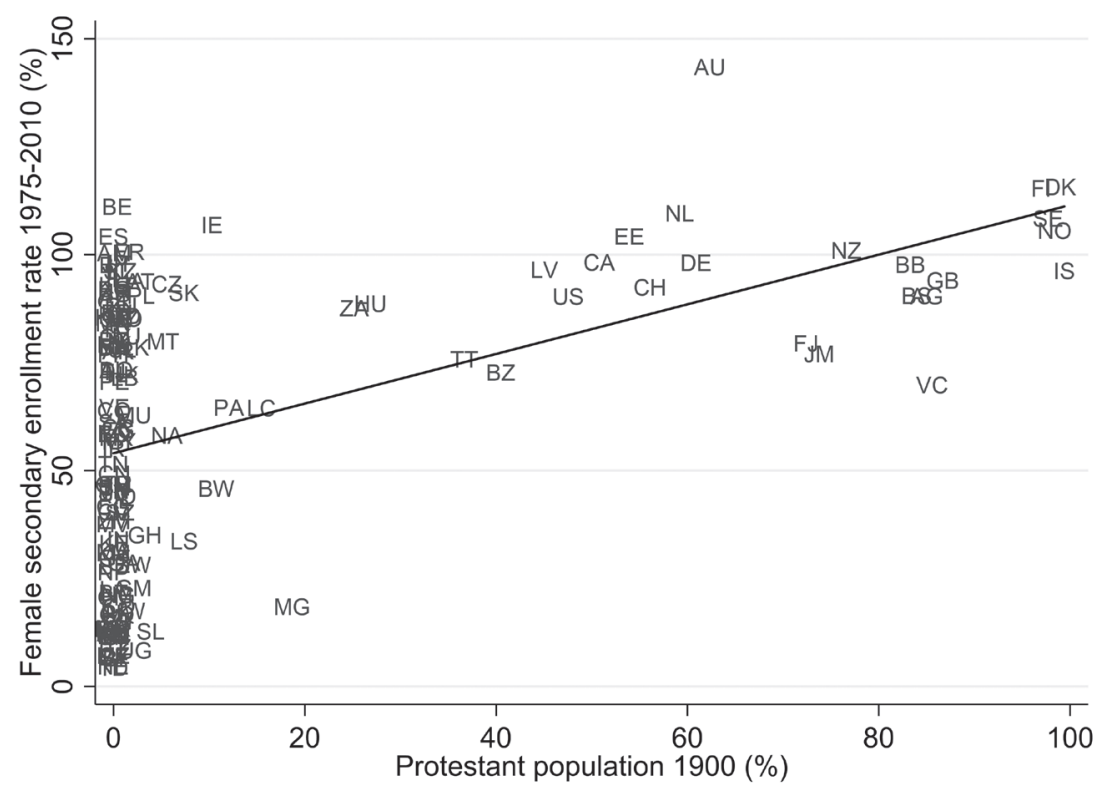

Note: 146 countries. The data for the Protestant population share are from the year 19oo. For the female secondary enrollment rate, country averages are calculated using quinquennial data from the period 1975 to 2010 . The regression represented by the fitted line yields a coefficient on 'Protestant population 1900' of 0.57 (robust standard error $=0.06$ ), $\mathrm{N}=146, R^{2}=0.22$.

FIGURE 2 Protestant population share and female secondary enrollment rate

that our Protestantism variables do not proxy for factors such as public spending on education, political freedom or GDP per capita. In the fixed effects regressions, there are two more reasons why our estimates are likely to be causal. First, in these regressions we are able to additionally control for unobserved country and year effects. Second, all explanatory variables (except year dummies) enter the fixed effects regressions with a lag of five years. Finally, it needs to be stressed that in our main regressions reverse causality (one of the main dimensions of endogeneity) is not an issue since in these regressions the religion data are from the year 1900, rather than from the 1975-2010 period. It is impossible for contemporary schooling (or other factors prevailing during that period) to have affected the Protestant population share that long ago.

Before we discuss the results from our multivariate regressions, let us briefly take a look at the bivariate associations between the historical Protestant 


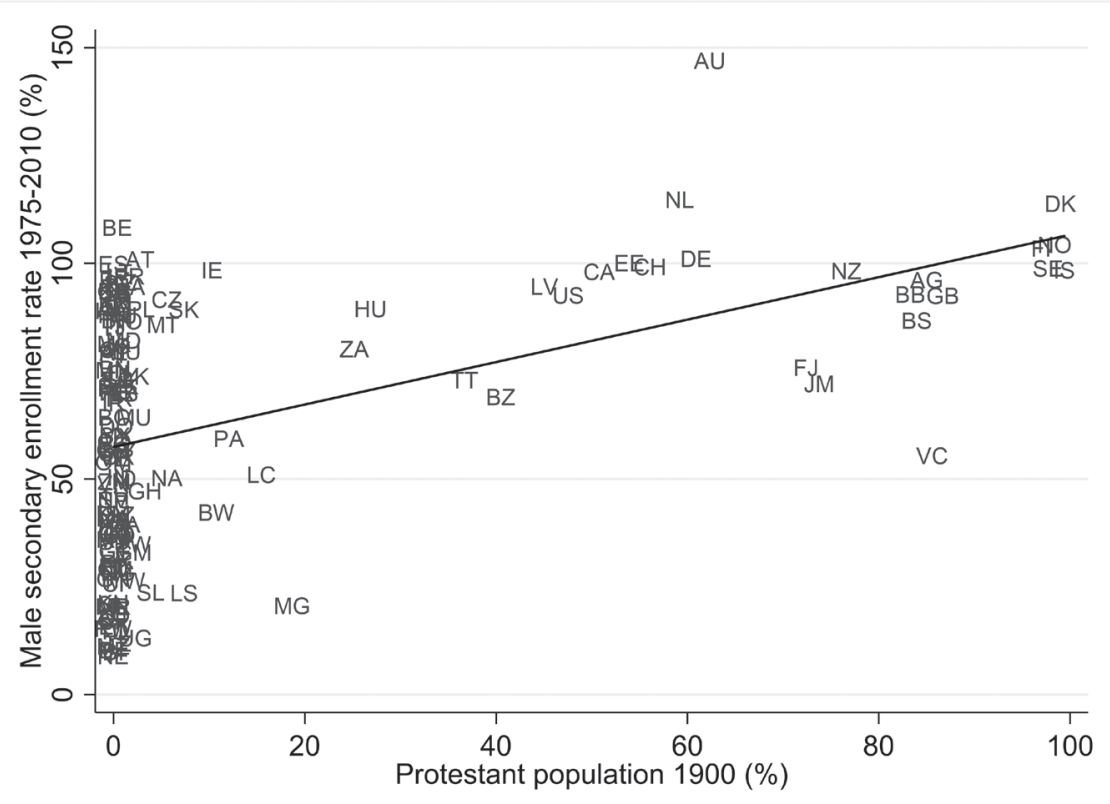

Note: 146 countries. The data for the Protestant population share are from the year 190o. For the male secondary enrollment rate, country averages are calculated using quinquennial data from the period 1975 to 2010. The regression represented by the fitted line yields a coefficient on 'Protestant population 1900' of 0.49 (robust standard error $=0.06$ ), $\mathrm{N}=146, R^{2}=0.20$.

FIGURE 3 Protestant population share and male secondary enrollment rate

population share, on the one hand, and the three contemporary enrollment variables, on the other (Figures 1-3). All figures show a positive relationship, which is mostly driven by roughly 30 countries. By and large, countries with higher Protestant population shares in 1900 tended to have higher secondary enrollment rates over 1975-2010, both among the group of boys and girls combined as well as among each of the two genders. Notably, the Nordic countries have the highest historical Protestant population shares and some of the highest contemporary enrollment rates. ${ }^{7}$

7 Figures $\mathrm{A}_{1}-\mathrm{A}_{3}$ in the Appendix take a closer look at countries with negligible Protestant population shares in 1900. Unsurprisingly, in these countries the correlation between these shares and the three enrollment variables is much weaker but, interestingly, it is positive as well. 
TABLE 1 Baseline regressions

(1)

Secondary enrollment rate

Protestantism 1900

Roman Catholicism 1900

Islam 1900

Eastern religions 1900

Public spending on education

Political rights \& civil liberties

Life expectancy

Death rate

Urbanization rate

Child population share

GDP per capita

GDP growth rate

Private credit

Openness

Former Spanish colony

Former French colony

Former British colony

Tropical area

Navigable waters
(2)

(3)

Male secondary enrollment rate enrollment rate

$\begin{array}{cc}16.52^{* * *} & 15.46^{* * *} \\ (4.85) & (4.77) \\ 1.27 & 0.35 \\ (4.06) & (3.68) \\ -4.82 & 0.00 \\ (4.85) & (4.56) \\ -12.18^{* *} & -9.35^{* *} \\ (5.53) & (4.68) \\ -0.51 & -39.29 \\ (59.13) & (60.34) \\ 1.45 & -0.92 \\ (6.20) & (5.47) \\ 0.50 & 0.06 \\ (0.75) & (0.66) \\ -19.06^{*} & -19.81^{* *} \\ (10.25) & (8.57) \\ 19.34^{* *} & 19.15^{* *} \\ (8.36) & (8.27) \\ -1.57^{* * *} & -1.70^{* * *} \\ (0.45) & (0.42) \\ -1.19 & 0.17 \\ (1.68) & (1.39) \\ -0.39 & -0.11 \\ (0.49) & (0.54) \\ -11.12^{* *} & -10.54^{* *} \\ (5.55) & (4.43) \\ 4.53 & 1.68 \\ (3.74) & (3.65) \\ -10.60^{* *} & -11.95^{* *} \\ (4.97) & (5.22) \\ -13.65^{* * *} & -10.13^{* * *} \\ (3.45) & (3.55) \\ -1.19 & -2.13 \\ (4.02) & (3.70) \\ -4.52 & -4.96 \\ (3.92) & (3.92) \\ -5.89 & -5.75 \\ (4.30) & (4.45) \\ & \\ & \\ (1.59) & \end{array}$


TABLE 1 Baseline regressions (cont.)

(1)

Secondary enrollment rate
(2)

Female secondary enrollment rate
(3)

Male secondary enrollment rate

\begin{tabular}{lccc}
\hline Number of observations & 147 & 146 & 146 \\
$R^{2}$ & 0.91 & 0.90 & 0.88 \\
$F$ statistic & $109.97^{* * *}$ & $108.46^{* * *}$ & $77 \cdot 39^{* * *}$ \\
Root mean squared error & 10.18 & 11.26 & 10.86
\end{tabular}

Note: OLS estimation. Dependent variables: 'secondary enrollment rate' (column 1), 'female secondary enrollment rate' (column 2) and 'male secondary enrollment rate' (column 3). The data for the religion variables are from the year 1900. The data for all other variables are averages over 1975, 1980, 1985, 1990, 1995, 2000, 2005 and 2010. All regressions additionally include a constant term. Robust standard errors are reported in parentheses. ${ }^{* * *}\left({ }^{* *} / *\right)$ denotes statistically significant at the $1 \%(5 \% / 10 \%)$ level.

Table 1 reports our main results. They are from our baseline regressions using religion adherence data from 1900 . While column 1 covers both genders jointly, columns 2 and 3 cover them separately. Note that our baseline regressions, as well as the regressions presented in Tables $2-5$, explain about $90 \%$ of the variation in the data. Thus the overall fit of the equations is very good. In all regressions reported in Table 1, the coefficient on 'Protestantism 1900' is positive and highly significant. This suggests that historical Protestantism has a favorable effect on contemporary secondary schooling. The magnitude of the estimated effect is small though. For example, countries in which the Protestant population share in 1900 was ten percentage points higher than in other countries had a secondary enrollment rate over 1975-2010 that was 1.5 percentage points higher, ceteris paribus. Columns 2 and 3 indicate that the estimated effects of 'Protestantism 190o' are very similar for girls and boys. This probably reflects the fact that Protestantism has always advocated that girls should receive as much education as boys (section 2).

Tables 2-4 present the results from our robustness checks. While Table 2 reports the results for the combined group of boys and girls, Tables 3 and 4 report those for girls and boys separately. As in the case of the baseline regressions, the robustness checks use religion adherence data from 1900. For brevity, the estimates for the baseline control variables are omitted in Tables 2-4. Each of the regressions in these tables uses the same controls as the baseline regressions of Table 1. The only exception is model 2 of Tables 2-4, in which two of the baseline control variables are replaced by two alternative ones. In all robustness checks, the coefficient on 'Protestantism 19oo' is positive and statistically 
TABLE 2 Robustness checks for secondary enrollment rate

\begin{tabular}{|c|c|c|c|c|c|}
\hline & $\begin{array}{l}(1) \\
\text { Nordic } \\
\text { countries } \\
\text { excluded }\end{array}$ & $\begin{array}{l}(2) \\
\text { Alternative } \\
\text { geographic } \\
\text { variables }\end{array}$ & $\begin{array}{l}\text { (3) } \\
\text { Elderly } \\
\text { population } \\
\text { share added }\end{array}$ & $\begin{array}{l}\text { (4) } \\
\text { Population } \\
\text { growth rate } \\
\text { added }\end{array}$ & $\begin{array}{l}\text { (5) } \\
\text { Fractionalization } \\
\text { variables added }\end{array}$ \\
\hline $\begin{array}{l}\text { Protestantism } \\
1900\end{array}$ & $\begin{array}{l}18.68^{* * *} \\
(5.10)\end{array}$ & $\begin{array}{l}11.44^{* *} \\
(4.91)\end{array}$ & $\begin{array}{l}14.77^{* * *} \\
(4.59)\end{array}$ & $\begin{array}{l}13.02^{* * *} \\
(4.59)\end{array}$ & $\begin{array}{l}14.14^{* * *} \\
(4.45)\end{array}$ \\
\hline $\begin{array}{l}\text { Roman Catholicism } \\
1900\end{array}$ & $\begin{array}{l}-2.17 \\
(4.06)\end{array}$ & $\begin{array}{l}-3.95 \\
(3.90)\end{array}$ & $\begin{array}{l}-1.5^{1} \\
(4.09)\end{array}$ & $\begin{array}{l}-2.07 \\
(4.01)\end{array}$ & $\begin{array}{l}-0.41 \\
(3.92)\end{array}$ \\
\hline Islam 1900 & $\begin{array}{l}-3.05 \\
(4.72)\end{array}$ & $\begin{array}{l}-4.60 \\
(4.57)\end{array}$ & $\begin{array}{l}-3.5^{0} \\
(4.74)\end{array}$ & $\begin{array}{l}-2.12 \\
(4.72)\end{array}$ & $\begin{array}{c}2.92 \\
(5.40)\end{array}$ \\
\hline $\begin{array}{l}\text { Eastern religions } \\
1900\end{array}$ & $\begin{array}{l}-8.92^{*} \\
(5.01)\end{array}$ & $\begin{array}{c}-11.88^{* *} \\
(5.15)\end{array}$ & $\begin{array}{c}-10.72^{* * *} \\
(5.11)\end{array}$ & $\begin{array}{c}-10.3^{* * *} \\
(4.82)\end{array}$ & $\begin{array}{l}-6.98 \\
(5.21)\end{array}$ \\
\hline Latitude & & $\begin{array}{c}21.84^{*} \\
(12.19)\end{array}$ & & & \\
\hline Landlocked & & $\begin{array}{c}3.02 \\
(2.45)\end{array}$ & & & \\
\hline $\begin{array}{l}\text { Elderly population } \\
\text { share }\end{array}$ & & & $\begin{array}{l}-0.67 \\
(1.07)\end{array}$ & & \\
\hline $\begin{array}{l}\text { Population growth } \\
\text { rate }\end{array}$ & & & & $\begin{array}{l}-3.22 \\
(2.20)\end{array}$ & \\
\hline $\begin{array}{l}\text { Ethnic } \\
\text { fractionalization }\end{array}$ & & & & & $\begin{array}{l}-2.17 \\
(5 \cdot 51)\end{array}$ \\
\hline $\begin{array}{l}\text { Religious } \\
\text { fractionalization }\end{array}$ & & & & & $\begin{array}{l}10.77^{*} \\
(5 \cdot 53)\end{array}$ \\
\hline $\begin{array}{l}\text { Baseline control } \\
\text { variables }\end{array}$ & Yes & Yes & Yes & Yes & Yes \\
\hline $\begin{array}{l}\text { Number of } \\
\text { observations }\end{array}$ & 142 & 147 & 147 & 147 & 146 \\
\hline$R^{2}$ & 0.90 & 0.90 & 0.91 & 0.91 & 0.91 \\
\hline$F$ statistic & $103 \cdot 5^{* * * *}$ & $112.31^{* * *}$ & $111.65^{* * *}$ & $107.67^{* * *}$ & $104.5^{2 * * *}$ \\
\hline $\begin{array}{l}\text { Root mean squared } \\
\text { error }\end{array}$ & 10.24 & 10.29 & 10.21 & 10.15 & 10.09 \\
\hline
\end{tabular}

Note: OLS estimation. Dependent variable: 'secondary enrollment rate'. The data for the religion variables are from the year 1900. The data for all other variables are averages over 1975, 1980, 1985, 1990, 1995, 2000, 2005 and 2010. Each regression additionally uses the same control variables as the baseline regressions (Table 1) - the only exception being regression 2, which includes neither 'tropical area' nor 'navigable waters'. For brevity, the estimates for the baseline control variables are omitted. All regressions also contain a constant term. Robust standard errors are reported in parentheses. ${ }^{* * *}(* * / *)$ denotes statistically significant at the $1 \%(5 \% / 10 \%)$ level. 
TABLE 3 Robustness checks for female secondary enrollment rate

\begin{tabular}{|c|c|c|c|c|c|}
\hline & $\begin{array}{l}(1) \\
\text { Nordic } \\
\text { countries } \\
\text { excluded }\end{array}$ & $\begin{array}{l}(2) \\
\text { Alternative } \\
\text { geographic } \\
\text { variables }\end{array}$ & $\begin{array}{l}(3) \\
\text { Elderly } \\
\text { population } \\
\text { share added }\end{array}$ & $\begin{array}{l}(4) \\
\text { Population } \\
\text { growth rate } \\
\text { added }\end{array}$ & $\begin{array}{l}(5) \\
\text { Fractionalization } \\
\text { variables added }\end{array}$ \\
\hline $\begin{array}{l}\text { Protestantism } \\
1900\end{array}$ & $\begin{array}{l}19.43^{* * *} \\
(5.63)\end{array}$ & $\begin{array}{l}14.50^{* * *} \\
(5.29)\end{array}$ & $\begin{array}{l}16.46^{* * *} \\
(4.86)\end{array}$ & $\begin{array}{l}14.36^{* * *} \\
(4.98)\end{array}$ & $\begin{array}{l}15.54^{* * *} \\
(4.71)\end{array}$ \\
\hline $\begin{array}{l}\text { Roman Catholicism } \\
1900\end{array}$ & $\begin{array}{c}0.56 \\
(4.08)\end{array}$ & $\begin{array}{l}-0.93 \\
(4.04)\end{array}$ & $\begin{array}{c}1.39 \\
(4.10)\end{array}$ & $\begin{array}{c}0.64 \\
(4.01)\end{array}$ & $\begin{array}{c}2.98 \\
(3.88)\end{array}$ \\
\hline Islam 1900 & $\begin{array}{l}-4.95 \\
(4.96)\end{array}$ & $\begin{array}{l}-6.00 \\
(4.78)\end{array}$ & $\begin{array}{l}-5.17 \\
(4.92)\end{array}$ & $\begin{array}{l}-3.42 \\
(4.81)\end{array}$ & $\begin{array}{c}1.99 \\
(6.11)\end{array}$ \\
\hline $\begin{array}{l}\text { Eastern religions } \\
1900\end{array}$ & $\begin{array}{r}-11.14^{*} \\
(5.66)\end{array}$ & $\begin{array}{c}-13.44^{* * *} \\
(5.61)\end{array}$ & $\begin{array}{c}-12.98^{* * *} \\
(5.73)\end{array}$ & $\begin{array}{c}-12.36^{* *} \\
(5.35)\end{array}$ & $\begin{array}{l}-7 \cdot 73 \\
(5 \cdot 76)\end{array}$ \\
\hline Latitude & & $\begin{array}{c}13.95 \\
(14.59)\end{array}$ & & & \\
\hline Landlocked & & $\begin{array}{c}4.29 \\
(2.70)\end{array}$ & & & \\
\hline $\begin{array}{l}\text { Elderly population } \\
\text { share }\end{array}$ & & & $\begin{array}{l}-1.09 \\
(1.23)\end{array}$ & & \\
\hline $\begin{array}{l}\text { Population growth } \\
\text { rate }\end{array}$ & & & & $\begin{array}{l}-3.87 \\
(2.56)\end{array}$ & \\
\hline $\begin{array}{l}\text { Ethnic } \\
\text { fractionalization }\end{array}$ & & & & & $\begin{array}{l}-5.85 \\
(6.15)\end{array}$ \\
\hline $\begin{array}{l}\text { Religious } \\
\text { fractionalization }\end{array}$ & & & & & $\begin{array}{l}13.73^{* * *} \\
(6.48)\end{array}$ \\
\hline $\begin{array}{l}\text { Baseline control } \\
\text { variables }\end{array}$ & Yes & Yes & Yes & Yes & Yes \\
\hline $\begin{array}{l}\text { Number of } \\
\text { observations }\end{array}$ & 141 & 146 & 146 & 146 & 145 \\
\hline$R^{2}$ & 0.90 & 0.90 & 0.90 & 0.90 & 0.90 \\
\hline$F$ statistic & $101.25^{* * *}$ & $113.43^{* * *}$ & $114.68^{* * *}$ & $104.47^{* * *}$ & $101.01^{* * *}$ \\
\hline $\begin{array}{l}\text { Root mean } \\
\text { squared error }\end{array}$ & 11.35 & 11.26 & 11.27 & 11.21 & 11.15 \\
\hline
\end{tabular}

Note: OLS estimation. Dependent variable: 'female secondary enrollment rate'. The data for the religion variables are from the year 1900. The data for all other variables are averages over 1975, 1980, 1985, 1990, 1995, 2000, 2005 and 2010. Each regression additionally uses the same control variables as the baseline regressions (Table 1 ) - the only exception being regression 2, which includes neither 'tropical area' nor 'navigable waters'. For brevity, the estimates for the baseline control variables are omitted. All regressions also contain a constant term. Robust standard errors are reported in parentheses. ${ }^{* * * * *}\left({ }^{*}\right)$ denotes statistically significant at the $1 \%(5 \% / 10 \%)$ level. 
TABLE 4 Robustness checks for male secondary enrollment rate

\begin{tabular}{|c|c|c|c|c|c|}
\hline & $\begin{array}{l}(1) \\
\text { Nordic } \\
\text { countries } \\
\text { excluded }\end{array}$ & $\begin{array}{l}(2) \\
\text { Alternative } \\
\text { geographic } \\
\text { variables }\end{array}$ & $\begin{array}{l}\text { (3) } \\
\text { Elderly } \\
\text { population } \\
\text { share added }\end{array}$ & $\begin{array}{l}\text { (4) } \\
\text { Population } \\
\text { growth rate } \\
\text { added }\end{array}$ & $\begin{array}{l}\text { (5) } \\
\text { Fractionalization } \\
\text { variables added }\end{array}$ \\
\hline $\begin{array}{l}\text { Protestantism } \\
1900\end{array}$ & $\begin{array}{l}20.09^{* * * *} \\
(5.93)\end{array}$ & $\begin{array}{l}13.29^{* *} \\
(5 \cdot 35)\end{array}$ & $\begin{array}{l}15.45^{* * * *} \\
(4.78)\end{array}$ & $\begin{array}{l}14.5^{8^{* * * *}} \\
(5.00)\end{array}$ & $\begin{array}{l}14.66^{* * * *} \\
(4.66)\end{array}$ \\
\hline $\begin{array}{l}\text { Roman Catholicism } \\
1900\end{array}$ & $\begin{array}{l}-0.23 \\
(3 \cdot 74)\end{array}$ & $\begin{array}{l}-1.68 \\
(3.65)\end{array}$ & $\begin{array}{c}0.38 \\
(3 \cdot 70)\end{array}$ & $\begin{array}{c}0.10 \\
(3.71)\end{array}$ & $\begin{array}{c}1.95 \\
(3.68)\end{array}$ \\
\hline Islam 1900 & $\begin{array}{c}0.54 \\
(4.62)\end{array}$ & $\begin{array}{l}-0.99 \\
(4.62)\end{array}$ & $\begin{array}{l}-0.08 \\
(4.65)\end{array}$ & $\begin{array}{c}0.57 \\
(4.59)\end{array}$ & $\begin{array}{c}7.11 \\
(5 \cdot 33)\end{array}$ \\
\hline $\begin{array}{l}\text { Eastern religions } \\
1900\end{array}$ & $\begin{array}{l}-7.98^{*} \\
(4.73)\end{array}$ & $\begin{array}{c}-10.64^{* *} \\
(4.88)\end{array}$ & $\begin{array}{l}-9.53^{*} \\
(4.87)\end{array}$ & $\begin{array}{l}-9.43^{\text {** }} \\
(4.66)\end{array}$ & $\begin{array}{l}-4.92 \\
(5.19)\end{array}$ \\
\hline Latitude & & $\begin{array}{c}12.59 \\
(13.98)\end{array}$ & & & \\
\hline Landlocked & & $\begin{array}{c}2.36 \\
(2.63)\end{array}$ & & & \\
\hline $\begin{array}{l}\text { Elderly population } \\
\text { share }\end{array}$ & & & $\begin{array}{l}-0.24 \\
(1.11)\end{array}$ & & \\
\hline $\begin{array}{l}\text { Population growth } \\
\text { rate }\end{array}$ & & & & $\begin{array}{l}-1.59 \\
(2.38)\end{array}$ & \\
\hline $\begin{array}{l}\text { Ethnic } \\
\text { fractionalization }\end{array}$ & & & & & $\begin{array}{l}-3.02 \\
(6.38)\end{array}$ \\
\hline $\begin{array}{l}\text { Religious } \\
\text { fractionalization }\end{array}$ & & & & & $\begin{array}{l}13.76^{* * *} \\
\left(6.5^{\circ}\right)\end{array}$ \\
\hline $\begin{array}{l}\text { Baseline control } \\
\text { variables }\end{array}$ & Yes & Yes & Yes & Yes & Yes \\
\hline $\begin{array}{l}\text { Number of } \\
\text { observations }\end{array}$ & 141 & 146 & 146 & 146 & 145 \\
\hline$R^{2}$ & 0.88 & 0.88 & 0.88 & 0.88 & o.89 \\
\hline$F$ statistic & $74.82^{* * * *}$ & $75 \cdot 16^{* * * *}$ & $81.05^{* * *}$ & $74.42^{* * *}$ & $72.68^{* * *}$ \\
\hline $\begin{array}{l}\text { Root mean squared } \\
\text { error }\end{array}$ & 10.87 & 11.01 & 10.90 & 10.88 & 10.73 \\
\hline
\end{tabular}

Note: OLS estimation. Dependent variable: 'male secondary enrollment rate'. The data for the religion variables are from the year 1900. The data for all other variables are averages over 1975, 1980, 1985, 1990, 1995, 2000, 2005 and 2010. Each regression additionally uses the same control variables as the baseline regressions (Table 1 ) - the only exception being regression 2 , which includes neither 'tropical area' nor 'navigable waters'. For brevity, the estimates for the baseline control variables are omitted. All regressions also contain a constant term. Robust standard errors are reported in parentheses. $\left.{ }^{* * * * * *} /{ }^{*}\right)$ denotes statistically significant at the $1 \%(5 \% / 10 \%)$ level. 
significant. In most of these checks, its size is close to the estimate from the respective baseline regression. Remarkably, when excluding the Nordic countries the magnitude of the effect is slightly larger, for both genders jointly as well as for each of them separately (column 1). Apparently, in the rest of the sample variations in historical Protestant population shares make an even larger difference to contemporary secondary schooling.

A brief comment on the estimates for the control variables (Tables 1-4). Several of them are in line with the previous literature (section 3). For example, we find urbanization to have a positive and mortality to have a negative effect on enrollment rates. A larger child population share has a negative effect as well. Also in line with previous research, we find that former colonies of both Spain and France have lower enrollment rates, ceteris paribus. Religious pluralism appears to favorably affect education. By contrast, countries that are in the tropics or closer to the equator might have lower secondary enrollment rates, although this finding is not robust. The insignificant results for some of the other control variables are also in line with some of the literature. Particularly, various previous papers find neither public spending on education nor political institutions to affect school enrollment (e.g., Glaeser et al. 2004, Papagapitos and Riley 2009).

Table 5 presents results from the regressions using contemporary rather than historical religion adherence data. In all other respects, the model is the same as the one used for the baseline regressions. The contemporary religion data are averaged over the same eight years as the data for the dependent and control variables. The estimates for the controls are omitted to save space. Strikingly, in all three regressions of Table 5 the coefficient on 'Protestantism' is much smaller than the one on 'Protestantism 190o' from the corresponding regressions in Table 1. It is also less precisely estimated. These results suggest that the influence of Protestantism on schooling has diminished, which is in line with the qualitative evidence summarized in section 2.

Table 6 presents results from regressions that also use contemporary religion adherence data. However, in contrast to the regressions of Table 5 they use annual data and country fixed effects. Thus they exclusively exploit variation within countries over 1975-2010. Again, the estimates for the controls are omitted. Notably, the coefficient on 'Protestantism' is statistically insignificant in each of the three fixed effects regressions. Thus a change in the Protestant population share is uncorrelated with a subsequent change in any of the three enrollment rates. ${ }^{8}$ This suggests that contemporary Protestantism does

8 As changes in the Protestant population share may take longer than five years to affect secondary enrollment rates, we increased the lag to ten years in an alternative fixed effects 
TABLE 5 Baseline regressions using contemporary religion data

(1)

$\begin{array}{ll}\text { Secondary } & \text { Female secondary } \\ \text { enrollment rate } & \text { enrollment rate }\end{array}$

(3)

Male secondary enrollment rate

\begin{tabular}{lccc}
\hline Protestantism & $11.02^{* *}$ & $10.33^{*}$ & $10.95^{*}$ \\
& $(5.06)$ & $(5.56)$ & $(5.89)$ \\
Roman Catholicism & -6.47 & -6.37 & -4.55 \\
& $(4.19)$ & $(4.70)$ & $(4.04)$ \\
Islam & -6.21 & $-8.80^{* *}$ & -3.14 \\
& $(4.49)$ & $(5.00)$ & $(4.50)$ \\
Eastern religions & -5.66 & -9.07 & -5.53 \\
& $(5.98)$ & $(6.90)$ & $(5.82)$ \\
Control variables & & & \\
Number of observations & Yes & Yes & Yes \\
$R^{2}$ & 146 & 145 & 145 \\
$F$ statistic & 0.90 & 0.90 & 0.88 \\
Root mean squared error & $111.57^{* * *}$ & $102.68^{* * *}$ & $79.65^{* * *}$ \\
& 10.28 & 11.32 & 11.04
\end{tabular}

Note: OLS estimation. Dependent variables: 'secondary enrollment rate' (column 1), 'female secondary enrollment rate' (column 2) and 'male secondary enrollment rate' (column 3). The data for all variables, including the religion variables, are averages over 1975, 1980, 1985, 1990, 1995, 2000, 2005 and 2010. The regressions use the same control variables as the baseline regressions (Table 1). For brevity, the estimates for these variables are omitted. All regressions additionally contain a constant term. Robust standard errors are reported in parentheses. ${ }^{* * *}\left({ }^{* *} / *^{*}\right)$ denotes statistically significant at the $1 \%(5 \% / 10 \%)$ level.

not significantly affect schooling. This is largely the result of nearly 200 years of secularization. There is a historical irony here. It had been the Protestant reformers who, from the start of the Reformation, had argued that schools should be run by the state and that children needed not only religious but also secular education (section 2). Thus, by initiating the process of secularization, the reformers unintentionally helped to bring about a situation in which contemporary Protestantism almost completely lost its previous influence on education.

For illustration, let us briefly revisit Germany, the country where Protestantism originated. Even though the Protestant church of Germany

specification. As it turned out, 'Protestantism' is statistically insignificant in such a model too (results not reported here). 
(1)

$\begin{array}{ll}\text { Secondary } & \text { Female secondary } \\ \text { enrollment rate } & \text { enrollment rate }\end{array}$

(3)

Male secondary

enrollment rate

\begin{tabular}{lccc}
\hline Protestantism & -2.82 & -3.19 & -1.54 \\
& $(17.85)$ & $(18.17)$ & $(18.52)$ \\
Roman Catholicism & -5.88 & -1.31 & -11.87 \\
& $(15.56)$ & $(13.68)$ & $(18.06)$ \\
Islam & -43.26 & $-48.50^{* *}$ & -31.56 \\
& $(27.19)$ & $(28.85)$ & $(27.31)$ \\
Eastern religions & 22.53 & 16.17 & 20.07 \\
& $(33.41)$ & $(34.86)$ & $(33.74)$ \\
Control variables & & & \\
Number of observations & Yes & Yes & Yes \\
Number of countries & 614 & 606 & 606 \\
$R^{2}$ within & 137 & 136 & 136 \\
$F$ statistic & 0.60 & 0.61 & 0.58 \\
Root mean squared error & $21.00^{* * *}$ & $21.96^{* * *}$ & $17.01^{* * *}$ \\
& 6.97 & 7.26 & 6.77 \\
\hline
\end{tabular}

Note: Pooled least squares regressions with country-specific fixed effects. Dependent variables: 'secondary enrollment rate' (column 1), 'female secondary enrollment rate' (column 2) and 'male secondary enrollment rate' (column 3 ). All variables, including the religion variables, use annual data for 1975, 1980, 1985, 1990, 1995, 2000, 2005 and 2010. The regressions reported here include neither colonial nor geographic controls as these variables are time-invariant. Apart from this, they use the same control variables as the baseline regressions (Table 1). Additionally, they use year dummies. For brevity, the estimates for the control variables and the year dummies are omitted. Each regression also contains a constant term. All explanatory variables (except year dummies) are lagged by five years. Robust standard errors, adjusted for clustering at the country level, are reported in parentheses. ${ }^{* * *}\left({ }^{*}\right)$ denotes statistically significant at the $1 \%(10 \%)$ level.

still claims its co-responsibility for education and schooling, contemporary Protestantism is hardly able to exert any influence. This is not only due to the fact that the German school system has long been secularized. It is also due to the fact that Germany's Protestant population share has fallen strongly since World War II (Maoz and Henderson 2013a). While it was about 50\% in the 1950 s and 1960s in West Germany, nowadays it is only about 30\% in Germany as a whole. Roughly $35 \%$ of Germans are non-religious. In East Germany, due to its Communist past, more than $50 \%$ are - despite the fact that it is home to Wittenberg, the birthplace of the Reformation (Posener 2013). The negligible influence of contemporary Protestantism notwithstanding, education is held in high regard throughout Germany (Milotich 1999). In large part, 
this is due to historical, certainly not to contemporary Protestantism. Since the Reformation, Protestantism helped to gradually create a cultural heritage that highly values education. By the mid-18th century, the predominantly Protestant middle class in Germany had become so fond of education that it was later called "Bildungsbürgertum" (Conze and Kocka 1985-92). Similar to Germany, in several other continental European as well as in all Nordic and Anglo-Saxon countries historical Protestantism was also instrumental in creating a cultural heritage that puts a high value on education (Hans 1967). As our regression results suggest, this cultural heritage is still alive today. They indicate that historical Protestantism has still positively affected schooling in recent years. Protestantism's original emphasis on education and schooling has long become part of the national culture in traditionally Protestant countries, and more recently in several former British colonies, particularly in Africa and the Caribbean (Bowen 1981). ${ }^{9}$

In contrast to the positive effect of historical Protestantism, the effect of Roman Catholicism is statistically insignificant throughout (Tables 1-6). This is unsurprising. Throughout history, the Catholic Church's approach to education differed substantially from that of Protestantism. Before the Reformation, school populations in Catholic countries were small, with literacy being largely limited to the clergy and the nobility (Bowen 1981). The sole purpose of education was to secure and promote Christian faith (Boyd and King 1975). In response to the Reformation, Rome became even more conservative. It tightened control of its schools, colleges and universities, persecuted heretics and promulgated an Index of Forbidden Books, which was abolished as late as 1966 (Burman 2004, Lenard 2006). Until the 19th century, the Catholic Church largely confined its educational initiatives to educating the male elite, both in the European countries where its monopoly remained in place - e.g., Spain and Portugal - as well as in these countries' colonies (Hans 1967, Feldmann 2016b). There were few educational opportunities for girls (Bowen 1981). Until the early to mid-2oth century, the Church resisted both mass education and

9 We also studied whether Protestantism exerts indirect or interaction effects. For example, it is conceivable that it affects secondary enrollment via public spending on education because it has always argued in favor of high spending in this area (section 2). Protestantism could also indirectly affect secondary enrollment via 'political rights \& civil liberties' because it has fostered the rise and spread of democracy (Woodberry 2012) and several papers find that democracy (or political freedom) increases enrollment rates (e.g., Lake and Baum 2001). Finally, by preaching a strong work ethic and thrift, Protestantism has spurred economic development, according to Weber (2001). Thus there could be an indirect effect of Protestantism on secondary enrollment via GDP per capita or GDP growth. However, we found no evidence for any of these indirect effects, nor for the corresponding interaction effects (results not reported here). 
equal education of girls (Foster Carroll 1983). It was only during the Second Vatican Council (1962-65) that it finally modernized its views in both regards (Fleming 2006). By that time, however, its influence on education had already strongly diminished (Hans 1967). Even in Catholic countries, governments had secularized and expanded education, especially after World War II (Feldmann 2016a). Thus by the 1970s the largely adverse effect Roman Catholicism has had on mass education throughout history had been overcome in most countries, which explains the insignificant coefficients on 'Roman Catholicism 190o' and 'Roman Catholicism' in our regressions.

Furthermore, we find contemporary Islam to adversely affect secondary schooling of girls. Specifically, countries in which the Muslim population share over 1975-2010 was ten percentage points higher than in other countries had a female secondary enrollment rate that was about 0.9 percentage points lower, ceteris paribus (Table 5). More strikingly, a ten percentage point increase in the share of Muslims in the population is associated with a reduction in the female secondary enrollment rate of almost five percentage points, ceteris paribus (Table 6). Together with the fact that 'Islam 19oo' is statistically insignificant (Tables 1-4), this suggests that the resurgence of Islam over recent decades has adversely affected female education. In most Muslim societies, not just in strictly Islamic ones, even today many girls are raised with the sole goal of being married, and after marriage a woman's primary role is to bear and raise children (Jawad 1998, Ibrahim 2011).

'Eastern religions 1900 ' is also negatively correlated with the female secondary enrollment rate and, to a lesser extent, with the male and the overall secondary enrollment rates (Tables 1-4). According to our estimates, countries in which the share of the population adhering to Eastern religions in 1900 was ten percentage points higher than in other countries had a female secondary enrollment rate over 1975-2010 that was about 1.2 percentage points lower, ceteris paribus (Tables 1 and 3). The negative effect on girls is probably because in societies dominated by an Eastern religion it has long been common to provide less education for them (Foster Carroll 1983, Kelleher 1987). Interestingly, in contrast to 'Eastern religions 1900', 'Eastern religions' is statistically insignificant (Tables 5 and 6). This may reflect that in recent decades these societies have rediscovered that most of their dominant religious dogmas have always put a high value on education (Gamage 2011, Sheshagiri 2011, Starr 2012). As a result, over the 1975-2010 period the previously negative effect of Eastern religions appears to have slowly vanished.

As mentioned in the introduction, since the mid-2oth century in most countries around the world, irrespective of their dominant religions, governments have strongly expanded secondary education (Lee and Lee 2016, Pew Research 
Center 2016). This massive expansion of government-provided education has weakened the influence of all religions and, consequently, reduces their statistical effects in our estimation.

Our regression results suggest that Protestantism still had a positive effect on secondary schooling in recent years. This is in spite of almost 200 years of secularization and a dramatic expansion of government-provided secondary education since the mid-2oth century. Although these two developments jointly have almost completely eliminated any influence of contemporary Protestantism on secondary schooling in most countries, Protestantism's original emphasis on education and schooling has long become part of the national culture in traditionally Protestant countries and, more recently, in several former British colonies. According to our estimates, this historical legacy has an enduring effect on secondary schooling. However, the magnitude of this effect is small. Moreover, Protestantism's traditional influence on schooling has diminished over time and contemporary Protestantism, in contrast to historical Protestantism, does not affect schooling.

Our regression results accord with other econometric studies of Protestantism (section 1). We add to this literature in several ways. Particularly, we combine historical with contemporary data and use an exceptionally large sample of countries. This enables us to derive a more general conclusion: the historically positive effect of Protestantism on schooling, though diminishing, is still noticeable today, and this is a global phenomenon.

Although our regressions control for many factors and the results are robust, more research is needed. Most importantly, the endogeneity issue needs to be tackled in a better way. Furthermore, the channels through which the historical legacy of Protestantism nowadays affects education and schooling should be systematically studied. For example, how does it influence parents' demand for and governments' supply of education and schooling? As education is of fundamental importance for personal and societal development, a better understanding of the influence Protestantism still exerts today is an important issue for future research. 


\section{References}

Alesina, Alberto, Reza Baqir and William Easterly. 1999. "Public Goods and Ethnic Divisions." Quarterly Journal of Economics 114(4): 1243-1284.

Alesina, Alberto, Arnaud Devleeschauwer, William Easterly, Sergio Kurlat and Romain Wacziarg. 2003. "Fractionalization." Journal of Economic Growth 8(2): 155-194.

Barro, Robert J. and Rachel M. McCleary. 2003. "Religion and Economic Growth across Countries." American Sociological Review 68(5): 760-781.

Becker, Gary S. and H. Gregg Lewis. 1973. "On the Interaction between the Quantity and Quality of Children.” Journal of Political Economy 81(2, 2): S279-S288.

Becker, Sascha O., Markus Nagler and Ludger Woessmann. 2017. "Education and Religious Participation: City-Level Evidence from Germany's Secularization Period 1890-1930." Journal of Economic Growth 22(3): 273-311.

Becker, Sascha O. and Ludger Woessmann. 2009. "Was Weber Wrong? A Human Capital Theory of Protestant Economic History." Quarterly Journal of Economics 124(2): 531-596.

Bellenoit, Hayden J. A. 2007. Missionary Education and Empire in Late Colonial India, 1860-1920. London: Pickering and Chatto.

Benavot, Aaron and Julia Resnik. 2006. "Lessons from the Past: A Comparative SocioHistorical Analysis of Primary and Secondary Education." Pp. 123-230 in Educating All Children: A Global Agenda, edited by Joel E. Cohen, David E. Bloom and Martin B. Malin. Cambridge (MA): MIT Press.

Benavot, Aaron and Phyllis Riddle. 1988. "The Expansion of Primary Education, 18701940: Trends and Issues." Sociology of Education 61(3): 191-210.

Berman, Edward H. 1975. "Christian Missions in Africa." Pp. 1-53 in African Reactions to Missionary Education, edited by Edward H. Berman. New York: Teachers College Press.

Bertinelli, Luisito and Benteng Zou. 2008. "Does Urbanization Foster Human Capital Accumulation?" Journal of Developing Areas 41(2): 171-184.

Bessey, Donata. 2013. "Religion and Educational Attainment in East Asia: First Evidence from the East Asian Social Survey." Global Economic Review 42(3): 238-250.

Beuttler, Fred W. 2012. "Rendering to the Kaiser': Protestantism, Education, and the State in German History." Pp. 163-193 in International Handbook of Protestant Education, edited by William Jeynes and David W. Robinson. Heidelberg: Springer.

Beyerlein, Kraig. 2004. "Specifying the Impact of Conservative Protestantism on Educational Attainment." Journal for the Scientific Study of Religion 43(4): 505-518.

Boppart, Timo, Josef Falkinger, Volker Grossmann, Ulrich Woitek and Gabriela Wüthrich. 2013. "Under Which Conditions Does Religion Affect Educational Outcomes?" Explorations in Economic History 50(2): 242-266. 
Bowen, James. 1975. A History of Western Education, Vol. 2: Civilization of Europe - Sixth to Sixteenth Century. London: Methuen.

Bowen, James. 1981. A History of Western Education, Vol. 3: The Modern West Europe and the New World. London: Methuen.

Boyd, William and Edmund J. King. 1975. The History of Western Education, 11th ed. London: Black.

Brañas-Garza, Pablo and Shoshana Neuman. 2004. "Analyzing Religiosity within an Economic Framework: The Case of Spanish Catholics." Review of Economics of the Household 2(1): 5-22.

Brown, Sarah and Karl Taylor. 2007. "Religion and Education: Evidence from the National Child Development Study." Journal of Economic Behavior and Organization $63(3): 439-460$.

Burman, Edward. 2004. The Inquisition: The Hammer of Heresy. Stroud: Sutton.

Center for International Development. 2001. "physfact_rev.xls" (Excel file). Center for International Development at Harvard University, Cambridge (Mass.).

Center for the Study of Global Christianity. 2007. "World Christian Database." Available at http://www.worldchristiandatabase.org, accessed 10 December 2007.

Cervellati, Matteo and Uwe Sunde. 2005. "Human Capital Formation, Life Expectancy, and the Process of Development." American Economic Review 95(5): 1653-1672.

Clignet, Remi P. and Philip J. Foster. 1964. "French and British Colonial Education in Africa." Comparative Education Review 8(2):191-198.

Conze, Werner and Jürgen Kocka (eds.). 1985-92. Bildungsbürgertum im 19. Jahrhundert, 4 volumes. Stuttgart: Klett-Cotta.

Cooray, Arusha and Niklas Potrafke. 2011. "Gender Inequality in Education: Political Institutions or Culture and Religion?" European Journal of Political Economy 27(2): 268-280.

Cox, Harvey. 1995. Fire from Heaven: The Rise of Pentecostal Spirituality and the Reshaping of Religion in the Twenty-First Century. Reading (MA): Addison-Wesley.

Cremin, Lawrence A. 1970. American Education: The Colonial Experience, 1607-1783. New York: Harper and Row.

Criblez, Lucien. 1999. "Der Bildungsartikel in der Bundesverfassung vom 29. Mai 1874." Pp. 337-362 in Eine Schule für die Demokratie: Zur Entwicklung der Volksschule in der Schweiz im 19. Jahrhundert, edited by Lucien Criblez, Carlo Jenzer, Rita Hofstetter and Charles Magnin. Bern: Lang.

De Gregorio, José. 1996. "Borrowing Constraints, Human Capital Accumulation, and Growth.” Journal of Monetary Economics 37(1): 49-71.

Elias, John L. 2002. A History of Christian Education: Protestant, Catholic, and Orthodox Perspectives. Malabar (FL): Krieger.

Engelsing, Rolf. 1973. Analphabetentum und Lektüre: Zur Sozialgeschichte des Lesens in Deutschland zwischen feudaler und industrieller Gesellschaft. Stuttgart: Metzler. 
Engerman, Stanley L., Elisa V. Mariscal and Kenneth L. Sokoloff. 2009. "The Evolution of Schooling in the Americas, 1800-1925." Pp. 93-142 in Human Capital and Institutions: A Long Run View, edited by David Eltis, Frank D. Lewis and Kenneth L. Sokoloff. Cambridge: Cambridge University Press.

Feenstra, Robert C., Robert Inklaar and Marcel P. Timmer. 2013. "Penn World Table 8.o." Available at http://www.rug.nl/research/ggdc/data/penn-world-table, accessed 23 July 2013 .

Feldmann, Horst. 2016a. "Which Religions Still Affect Schooling? A Study of 143 Countries." Comparative Sociology 15(4): 439-484.

Feldmann, Horst. 2016b. "The Long Shadows of Spanish and French Colonial Education." Kyklos 69(1): 32-64.

Fleming, G. P. (Joe). 2006. "Catholic Church Documents on Religious Education." Pp. 607-620 in International Handbook of the Religious, Moral and Spiritual Dimensions in Education, Part 1, edited by Marian de Souza, Gloria Durka, Kathleen Engebretson, Robert Jackson and Andrew McGrady. Dordrecht: Springer.

Foster Carroll, Theodora. 1983. Women, Religion, and Development in the Third World. New York: Praeger.

Frankema, Ewout H. P. 2012. "The Origins of Formal Education in Sub-Saharan Africa: Was British Rule More Benign?" European Review of Economic History 16(4): 335-355.

Freedom House. 2014. "Freedom in the World 2014." Available at https://freedomhouse .org, accessed 20 April 2014.

Gallego, Francisco A. and Robert Woodberry. 2010. "Christian Missionaries and Education in Former African Colonies: How Competition Mattered." Journal of African Economies 19(3): 294-329.

Gallup, John Luke, Jeffrey D. Sachs and Andrew D. Mellinger. 1999. "Geography and Economic Development." International Regional Science Review 22(2): 179-232.

Gamage, David T. 2011. "A Cultural Overview of the Education Systems in Buddhist Countries." Pp. 389-402 in Handbook of Asian Education: A Cultural Perspective, edited by Yong Zhao, Jing Lei, Guofang Li, Ming Fang He, Kaori Okano, Nagwa Megahed, David Gamage and Hema Ramanathan. New York: Routledge.

Gifford, Prosser and Timothy C. Weiskel. 1971. "African Education in a Colonial Context: French and British Styles." Pp. 663-711 in France and Britain in Africa: Imperial Rivalry and Colonial Rule, edited by Prosser Gifford and W. M. Roger Louis. New Haven (CT): Yale University Press.

Glaeser, Edward L., Rafael La Porta, Florencio Lopez-de-Silanes and Andrei Shleifer. 2004. “Do Institutions Cause Growth?" Journal of Economic Growth 9(3): 271-303.

Gokcekus, Omer. 2008. "Is it Protestant Tradition or Current Protestant Population that Affects Corruption?" Economics Letters 99(1): 59-62. 
Green, Lowell. 1979. "The Education of Women in the Reformation." History of Education Quarterly 19(1): 93-116.

Gruber, Jonathan H. 2005. "Religious Market Structure, Religious Participation, and Outcomes: Is Religion Good for You?" Advances in Economic Analysis and Policy 5(1): 1-30.

Hans, Nicholas. 1967. Comparative Education: A Study of Educational Factors and Traditions, 3rd ed. London: Routledge \& Kegan Paul.

Harran, Marilyn J. 1997. Martin Luther: Learning for Life. St. Louis (MO): Concordia Publishing House.

Holborn, Hajo. 1959. A History of Modern Germany: The Reformation. New York: Knopf. Hsu, Becky, Amy Reynolds, Conrad Hackett and James Gibbon. 2008. "Estimating the Religious Composition of All Nations: An Empirical Assessment of the World Christian Database." Journal for the Scientific Study of Religion 47(4): 678-693.

Hungerman, Daniel M. 2014. "The Effect of Education on Religion: Evidence from Compulsory Schooling Laws." Journal of Economic Behavior and Organization 104: $5^{2-63}$

Ibrahim, Ali S. 2011. "Education in the United Arab Emirates: A Socio-cultural Analysis." Pp. 327-344 in Handbook of Asian Education: A Cultural Perspective, edited by Yong Zhao, Jing Lei, Guofang Li, Ming Fang He, Kaori Okano, Nagwa Megahed, David Gamage and Hema Ramanathan. New York: Routledge.

IMF. 2014. "World Economic Outlook Database, April 2014 Edition." Available at http:// www.imf.org, accessed 9 May 2014.

Inglehart, Ronald and Wayne E. Baker. 2000. "Modernization, Cultural Change, and the Persistence of Traditional Values." American Sociological Review 65(1): 19-51.

Jawad, Haifaa A. 1998. The Rights of Women in Islam: An Authentic Approach. Basingstoke: Macmillan.

Jeynes, William. 2012. "An Overview of Protestant Education in Africa." Pp. 327-339 in International Handbook of Protestant Education, edited by William Jeynes and David W. Robinson. Heidelberg: Springer.

Kelleher, Theresa. 1987. “Confucianism.” Pp. 135-160 in Women in World Religions, edited by Arvind Sharma. Albany (NY): State University of New York Press.

Kirchenamt der Evangelischen Kirche in Deutschland (ed.). 2013. Education from a Protestant Perspective: A Collection of Documents from the Evangelical Church in Germany. Gütersloh: Gütersloher Verlagshaus.

Lake, David A. and Matthew A. Baum. 2001. "The Invisible Hand of Democracy: Political Control and the Provision of Public Services." Comparative Political Studies 34(6): 587-621.

Lamberti, Marjorie. 2002. The Politics of Education: Teachers and School Reform in Weimar Germany. New York: Berghahn. 
La Porta, Rafael, Florencio Lopez-de-Silanes, Andrei Shleifer and Robert Vishny. 1999. "The Quality of Government." Journal of Law, Economics, and Organization 15(1): 222-279.

Lee, Jong-Wha and Hanol Lee. 2016. "Human Capital in the Long Run." Journal of Development Economics 122: 147-169.

Lehrer, Evelyn L. 1999. "Religion as a Determinant of Educational Attainment: An Economic Perspective." Social Science Research 28(4): 358-379.

Lenard, Max. 2006. "On the Origin, Development and Demise of the Index Librorum Prohibitorum." Journal of Access Services 3(4): 51-63.

Maoz, Zeev and Errol A. Henderson. 2013a. "The World Religion Dataset, Version 1.1." Available at http://www.correlatesofwar.org, accessed 11 February 2014.

Maoz, Zeev and Errol A. Henderson. 2013b. "The World Religion Dataset, 1945-2010: Logic, Estimates, and Trends." International Interactions 39(3): 265-291.

Massengill, Rebekah Peeples. 2008. "Educational Attainment and Cohort Change among Conservative Protestants, 1972-2004." Journal for the Scientific Study of Religion 47(4): 545-562.

McGrath, Alister E. 2007. Christianity's Dangerous Idea: The Protestant Revolution - A History from the Sixteenth Century to the Twenty-First. New York: HarperOne.

Méndez, Fabio and Facundo Sepúlveda. 2012. "The Cyclicality of Skill Acquisition: Evidence from Panel Data." American Economic Journal: Macroeconomics 4(3): 128-152.

Milotich, Mark F. 1999. “The Role of School in German Adolescents' Lives.” Pp. 133-186 in The Educational System in Germany: Case Study Findings, edited by Mark A. Ashwill. Washington, D.C.: US Department of Education.

Mincer, Jacob. 1996. "Economic Development, Growth of Human Capital, and the Dynamics of the Wage Structure." Journal of Economic Growth 1(1): 29-48.

Mitchell, Peter. 1993. "Protestantism and Educational Provision." Pp. 125-143 in World Religions and Educational Practice, edited by Witold Tulasiewicz and Cho-Yee To. London: Cassell.

Mocan, Naci and Luiza Pogorelova. 2014. "Compulsory Schooling Laws and Formation of Beliefs: Education, Religion and Superstition.” NBER Working Paper No. 20557, NBER, Cambridge (MA).

Neal, Derek. 1997. "The Effects of Catholic Secondary Schooling on Educational Achievement." Journal of Labor Economics 15(1, 1): 98-123.

Nord, Warren A. 1995. Religion and American Education:Rethinking a NationalDilemma. Chapel Hill (NC): University of North Carolina Press.

Norton, Seth W. and Annette Tomal. 2009. "Religion and Female Educational Attainment." Journal of Money, Credit and Banking 41(5): 961-986.

Papagapitos, Agapitos and Robert Riley. 2009. "Social Trust and Human Capital Formation." Economics Letters 102(3): 158-160. 
Paulsen, Friedrich. 1908. German Education: Past and Present. London: Fisher Unwin.

Pew Research Center. 2006. Spirit and Power: A 10-Country Survey of Pentecostals. Washington, D.C.: Pew Research Center.

Pew Research Center. 2011. Global Christianity: A Report on the Size and Distribution of the World's Christian Population. Washington, D.C.: Pew Research Center.

Pew Research Center. 2014. Religion in Latin America: Widespread Change in a Historically Catholic Region. Washington, D.C.: Pew Research Center.

Pew Research Center. 2016. Religion and Education Around the World. Washington, D.C.: Pew Research Center.

Posener, Alan. 2013. „Ostdeutschland - die ungläubigste Region der Welt.“ Die Welt. Available at https://www.welt.de, accessed 19 April 2017.

Poterba, James M. 1997. "Demographic Structure and the Political Economy of Public Education." Journal of Policy Analysis and Management 16(1): 48-66.

Ranjan, Priya. 2001. "Dynamic Evolution of Income Distribution and Credit-Constrained Human Capital Investment in Open Economies." Journal of International Economics 55(2): 329-358.

Reich, Jerome R. 2011. Colonial America, 6th ed. Boston (MA): Prentice Hall.

Robinson, David W. 2012. "Notes on Protestant Education in England." Pp. 225-244 in International Handbook of Protestant Education, edited by William Jeynes and David W. Robinson. Heidelberg: Springer.

Romeiro, Paulo. 2012. "Protestant Education in Brazil." Pp. 399-416 in International Handbook of Protestant Education, edited by William Jeynes and David W. Robinson. Heidelberg: Springer.

Ryrie, Alec. 2017. Protestants: The Radicals Who Made the Modern World. London: William Collins.

Schleunes, Karl A. 1989. Schooling and Society: The Politics of Education in Prussia and Bavaria, 1750-1900. Oxford: Berg.

Sherkat, Darren E. 2011. "Religion and Scientific Literacy in the United States." Social Science Quarterly 92(5): 1134-1150.

Sheshagiri, K. M. 2011. "A Cultural Overview of Education in Hindu Civilization." Pp. 463-480 in Handbook of Asian Education: A Cultural Perspective, edited by Yong Zhao, Jing Lei, Guofang Li, Ming Fang He, Kaori Okano, Nagwa Megahed, David Gamage and Hema Ramanathan. New York: Routledge.

Sikkink, David. 1999. "The Social Sources of Alienation from Public Schools." Social Forces 78(1): 51-86.

Starr, Don. 2012. "China and the Confucian Education Model." Available at http://www .universitas21.com, accessed 4 September 2015.

Stoler, Avraham and David Meltzer. 2013. "Mortality and Morbidity Risks and Economic Behavior." Health Economics 22(2): 132-143. 
Strauss, Gerald. 1978. Luther's House of Learning: Indoctrination of the Young in the German Reformation. Baltimore (MD): John Hopkins University Press.

Sundkler, Bengt and Christopher Steed. 2000. A History of the Church in Africa. Cambridge: Cambridge University Press.

Swarup, Ram. 2000 [1971]. "The Hindu View of Education.” In On Hinduism: Reviews and Reflections, by Ram Swarup. Available at http://voiceofdharma.org, accessed 21 August 2015.

To, Cho-Yee. 1993. "Confucianism in East Asia." Pp. 72-83 in World Religions and Educational Practice, edited by Witold Tulasiewicz and Cho-Yee To. London: Cassell.

Trostel, Philip A. 2002. "Should Education Be Publicly Provided?" Bulletin of Economic Research 54(4): 373-391.

UNESCO Institute for Statistics. 2015. "Education Statistics." Available at http://www. uis.unesco.org, accessed 2 September 2015.

Vergon, Charles B. (ed.). 1986. The Church, the State and the Schools: Contemporary Issues in Law and Policy. Ann Arbor (MI): University of Michigan School of Education.

Weber, Max. 2001 [1920]. The Protestant Ethic and the "Spirit" of Capitalism. London: Routledge.

Welter, Rush. 1962. Popular Education and Democratic Thought in America. New York: Columbia University Press.

White, Bob W. 1996. "Talk about School: Education and the Colonial Project in French and British Africa (1860-1960)." Comparative Education 32(1): 9-25.

Woodberry, Robert D. 2012. "The Missionary Roots of Liberal Democracy." American Political Science Review 106(2): 244-274.

Woodberry, Robert D. and Timothy S. Shah. 2004. "The Pioneering Protestants." Journal of Democracy 15(2): 47-61.

World Bank. 2013. "Global Financial Development Database." Available at http://data. worldbank.org, accessed 6 January 2014.

World Bank. 2014. "World Development Indicators." Available at http://data.worldbank.org, accessed 6 June 2014.

\section{Appendices}

\section{Definitions and Sources of Variables}

Child population share. Population between the ages o to 14 years as a percentage of the total population. Source: World Bank (2014).

Death rate. Number of deaths per 100 people. Source: World Bank (2014). 
Eastern religions. Decimal fraction of the population adhering to an Eastern religion such as Buddhism or Hinduism. Source: Maoz and Henderson (2013a), author's calculations.

Eastern religions 1900. Decimal fraction of the population who, in 1900, adhered to an Eastern religion. Source: Center for the Study of Global Christianity (2007), author's calculations.

Elderly population share. Population ages 65 years and older as a percentage of the total population. Source: World Bank (2014).

Ethnic fractionalization. One minus the Herfindahl index of ethnic group shares, reflecting the probability that two randomly selected individuals from a population belong to different groups. Source: Alesina et al. (2003).

Female secondary enrollment rate. Girls enrolled in secondary education, regardless of age, as a percentage of girls in the age group that officially corresponds to this level of education. Source: UNESCO Institute for Statistics (2015).

Former British colony. Dummy variable that takes the value 1 if the respective country is a former British overseas colony. Former British settler colonies that enjoyed broad privileges of home rule are excluded (Australia, Canada, Israel, New Zealand and United States). Source: Author's classification.

Former French colony. Dummy variable that takes the value 1 if the respective country is a former French overseas colony. Source: Author's classification.

Former Spanish colony. Dummy variable that takes the value 1 if the respective country is a former Spanish overseas colony. Source: Author's classification.

GDP growth rate. Annual percentage growth rate of real GDP. Source: IMF (2014), World Bank (2014).

GDP per capita. Expenditure side real GDP per capita at chained purchasing power parity rates, in tens of thousands of 2005 US dollars. Source: Feenstra et al. (2013), author's calculations.

Islam. Decimal fraction of the population adhering to Islam. Source: Maoz and Henderson (2013a).

Islam 1900. Decimal fraction of the population who, in 1900, adhered to Islam. Source: Center for the Study of Global Christianity (2007).

Landlocked. Dummy variable that takes the value 1 if a country has no coastal territory on an ocean or on a sea linked to an ocean. Source: Author's classification.

Latitude. The absolute value of the latitude of the country's capital city, scaled to take values between o and 1. Source: La Porta et al. (1999).

Life expectancy. Life expectancy at birth in years. Source: World Bank (2014).

Male secondary enrollment rate. Boys enrolled in secondary education, regardless of age, as a percentage of boys in the age group that officially corresponds to this level of education. Source: UNESCO Institute for Statistics (2015). 
Navigable waters. Share of land area within $100 \mathrm{~km}$ of an ocean or ocean-navigable river, excluding coastline above the winter extent of sea ice and the rivers that flow to this coastline. Source: Center for International Development (2001).

Openness. Sum of exports and imports of goods and services as a decimal fraction of GDP. Source: World Bank (2014).

Political rights \& civil liberties. Average of political rights and civil liberties ratings, scaled to range from o to 1 , with higher values representing more rights and liberties. Source: Freedom House (2014), author's calculations.

Population growth rate. Annual percentage growth rate of the population. Source: World Bank (2014).

Private credit. The financial resources provided to the private sector by financial institutions as a decimal fraction of GDP. Source: World Bank (2013).

Protestantism. Decimal fraction of the population adhering to Protestantism. Source: Maoz and Henderson (2013a), author's calculations.

Protestantism 1900. Decimal fraction of the population who, in 1900, adhered to Protestantism. Source: Center for the Study of Global Christianity (2007), author's calculations.

Public spending on education. Public spending on education as a decimal fraction of GDP. Source: World Bank (2014).

Religious fractionalization. One minus the Herfindahl index of religious group shares, reflecting the probability that two randomly selected individuals from a population belong to different groups. Source: Alesina et al. (2003).

Roman Catholicism. Decimal fraction of the population adhering to Roman Catholicism. Source: Maoz and Henderson (2013a).

Roman Catholicism 1900. Decimal fraction of the population who, in 1900, adhered to Roman Catholicism. Source: Center for the Study of Global Christianity (2007).

Secondary enrollment rate. Children enrolled in secondary education, regardless of age, as a percentage of the age group that officially corresponds to this level of education. Source: UNES Co Institute for Statistics (2015).

Tropical area. Share of land area in geographical tropics. Source: Center for International Development (2001).

Urbanization rate. People living in urban areas as a decimal fraction of the total population. Source: World Bank (2014). 


\section{Descriptive Statistics}

TABLE A1 Descriptive statistics

Mean Std. dev. Min. Max.

\begin{tabular}{|c|c|c|c|c|}
\hline \multirow[b]{2}{*}{ Secondary enrollment rate } & \multicolumn{4}{|c|}{ Dependent variables } \\
\hline & 62.06 & 30.96 & 6.86 & $127 \cdot 47$ \\
\hline Female secondary enrollment rate & 61.31 & 33.24 & 4.47 & 143.60 \\
\hline \multirow[t]{2}{*}{ Male secondary enrollment rate } & 63.67 & 29.63 & 9.09 & 147.11 \\
\hline & \multicolumn{4}{|c|}{ Religion variables } \\
\hline Protestantism 1900 & 0.13 & 0.27 & 0.00 & 0.99 \\
\hline Roman Catholicism 1900 & 0.26 & 0.38 & 0.00 & 1.00 \\
\hline Islam 1900 & 0.19 & 0.34 & 0.00 & 1.00 \\
\hline Eastern religions 1900 & 0.08 & 0.24 & 0.00 & 0.99 \\
\hline Protestantism & 0.14 & 0.21 & 0.00 & 0.92 \\
\hline Roman Catholicism & 0.30 & 0.34 & 0.00 & 0.95 \\
\hline Islam & 0.23 & 0.35 & 0.00 & 0.99 \\
\hline \multirow[t]{2}{*}{ Eastern religions } & 0.07 & 0.20 & 0.00 & 0.95 \\
\hline & \multicolumn{4}{|c|}{ Control variables } \\
\hline Public spending on education & 0.04 & 0.02 & 0.01 & 0.16 \\
\hline Political rights \& civil liberties & 0.54 & 0.29 & 0.03 & 1.00 \\
\hline Life expectancy & 65.14 & 10.11 & $39 \cdot 72$ & 79.13 \\
\hline Death rate & 1.03 & 0.41 & 0.34 & 2.37 \\
\hline Urbanization rate & $0.5^{1}$ & 0.23 & 0.07 & 0.97 \\
\hline Child population share & $33 \cdot 5^{6}$ & $9 \cdot 93$ & 16.50 & 48.29 \\
\hline GDP per capita & 0.94 & 1.00 & 0.05 & 5.72 \\
\hline GDP growth rate & 3.69 & 2.21 & -5.64 & $9 \cdot 35$ \\
\hline Private credit & 0.41 & 0.34 & 0.01 & 1.68 \\
\hline Openness & 0.81 & 0.40 & 0.20 & 2.72 \\
\hline Former Spanish colony & 0.12 & 0.32 & 0.00 & 1.00 \\
\hline Former French colony & 0.17 & 0.38 & 0.00 & 1.00 \\
\hline Former British colony & 0.27 & 0.45 & 0.00 & 1.00 \\
\hline Tropical area & 0.49 & 0.48 & 0.00 & 1.00 \\
\hline Navigable waters & $0.5^{1}$ & 0.39 & 0.00 & 1.00 \\
\hline Latitude & 0.30 & 0.19 & 0.00 & 0.72 \\
\hline
\end{tabular}




\begin{tabular}{lcccr}
\hline & Mean & Std. dev. & Min. & Max. \\
\hline Landlocked & 0.24 & 0.43 & 0.00 & 1.00 \\
Elderly population share & 6.85 & 4.39 & 2.09 & 17.08 \\
Population growth rate & 1.67 & 1.08 & -0.50 & 4.39 \\
Ethnic fractionalization & 0.44 & 0.26 & 0.00 & 0.93 \\
Religious fractionalization & 0.44 & 0.23 & 0.00 & 0.86 \\
\hline
\end{tabular}

Note: The statistics were calculated using country-averaged data.

\section{List of Countries}

Albania, Angola, Antigua and Barbuda, Argentina, Armenia, Australia, Austria, Azerbaijan, Bahamas, Bahrain, Bangladesh, Barbados, Belarus, Belgium, Belize, Benin, Bhutan, Bolivia, Botswana, Brazil, Brunei Darussalam, Bulgaria, Burkina Faso, Burundi, Cabo Verde, Cambodia, Cameroon, Canada, Central African Republic, Chad, Chile, China, Colombia, Comoros, Costa Rica, Côte d'Ivoire, Croatia, Cyprus, Czech Republic, Democratic Republic of the Congo, Denmark, Djibouti, Dominican Republic, Ecuador, Egypt, El Salvador, Equatorial Guinea, Estonia, Ethiopia, Fiji, Finland, France, Gabon, Gambia, Georgia, Germany, Ghana, Greece, Guatemala, Guinea, Honduras, Hong Kong, Hungary, Iceland, India, Indonesia, Iran, Ireland, Israel, Italy, Jamaica, Japan, Jordan, Kazakhstan, Kenya, Kuwait, Kyrgyzstan, Laos, Latvia, Lebanon, Lesotho, Lithuania, Luxembourg, Macedonia, Madagascar, Malawi, Malaysia, Maldives, Mali, Malta, Mauritania, Mauritius, Mexico, Moldova, Mongolia, Morocco, Mozambique, Namibia, Nepal, Netherlands, New Zealand, Niger, Nigeria, Norway, Oman, Pakistan, Panama, Paraguay, Peru, Philippines, Poland, Portugal, Republic of the Congo, Romania, Russia, Rwanda, Saint Lucia, Saint Vincent and the Grenadines, Saudi Arabia, Senegal, Sierra Leone, Slovakia, Slovenia, South Africa, South Korea, Spain, Sri Lanka, Swaziland, Sweden, Switzerland, Syria, Tajikistan, Tanzania, Thailand, Togo, Trinidad and Tobago, Tunisia, Turkey, Uganda, Ukraine, United Kingdom, United States, Uruguay, Venezuela, Vietnam, Zambia, Zimbabwe. 


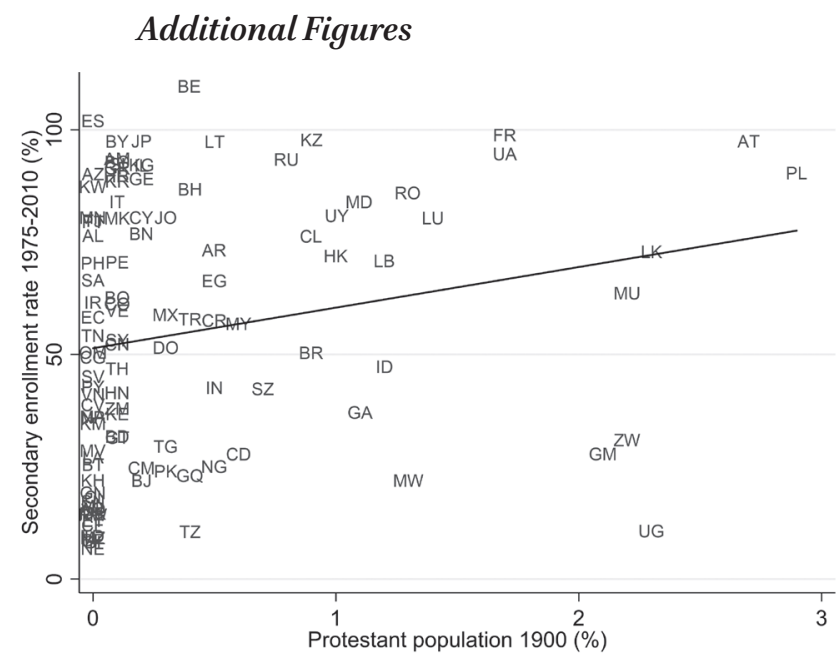

Note: 110 countries. This figure shows only countries with a Protestant population share of up to $3 \%$. The data for the Protestant population share are from the year 19oo. For the secondary enrollment rate, country averages are calculated using quinquennial data from the period 1975 to 2010 . The regression represented by the fitted line yields a coefficient on 'Protestant population 1900' of 9.04 (robust standard error $=4.41$ ), $\mathrm{N}=110, R^{2}=0.04$.

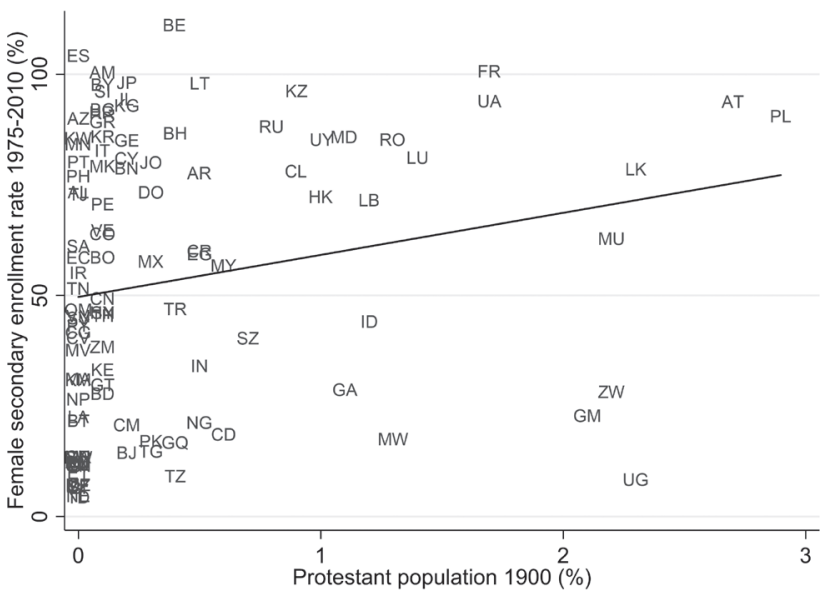

Note: 109 countries. This figure shows only countries with a

Protestant population share of up to $3 \%$. The data for the Protestant population share are from the year 1900 . For the female secondary enrollment rate, country averages are calculated using quinquennial data from the period 1975 to 2010 . The regression represented by the fitted line yields a coefficient on 'Protestant population 190o' of 9.51 (robust standard error $=4.64$ ), $\mathrm{N}=109, R^{2}=0.04$.
FIGURE A1

Protestant population share up to $3 \%$ and secondary enrollment rate.

FIGURE A2

Protestant population share up to $3 \%$ and female secondary enrollment rate. 


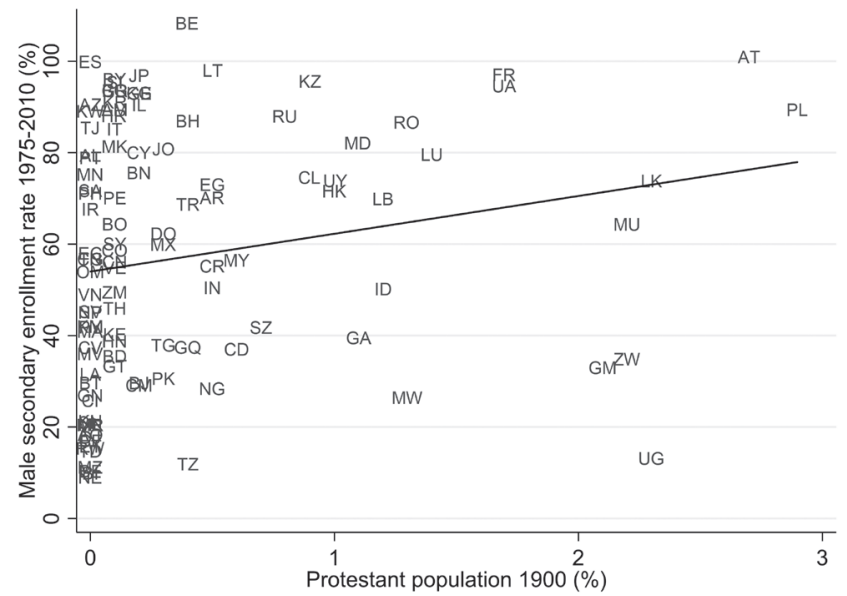

Note: 109 countries. This figure shows only countries with a Protestant population share of up to $3 \%$. The data for the Protestant population share are from the year 1900. For the male secondary enrollment rate, country averages are calculated using quinquennial data from the period 1975 to 2010 . The regression represented by the fitted line yields a coefficient on 'Protestant population 19oo' of 8.26 (robust standard error $=4.24$ ), $\mathrm{N}=109, R^{2}=0.04$.
FIGURE A3

Protestant population share up to $3 \%$ and male secondary enrollment rate. 